\title{
Soil fertility controls soil-atmosphere carbon dioxide and methane fluxes in a tropical landscape converted from lowland forest to rubber and oil palm plantations
}

\author{
E. Hassler ${ }^{1}$, M. D. Corre ${ }^{1}$, A. Tjoa ${ }^{2}$, M. Damris ${ }^{3}$, S. R. Utami ${ }^{4}$, and E. Veldkamp ${ }^{1}$ \\ ${ }^{1}$ Soil Science of Tropical and Subtropical Ecosystems, Büsgen Institute, Georg August University of Göttingen, \\ Büsgenweg 2, 37077 Göttingen, Germany \\ ${ }^{2}$ Faculty of Agriculture, Tadulako University, Jl. Soekarno Hatta, km 09 Tondo, Palu 94118, Indonesia \\ ${ }^{3}$ Department of Chemical Engineering, Faculty of Engineering, Jambi University, Jl. Tribrata, Km 11, \\ Pondok Meja, Muaro Jambi, Jambi, Indonesia \\ ${ }^{4}$ Department of Soil Science, Faculty of Agriculture, Brawijaya University, Jl. Veteran 1, Malang 65145, Indonesia
}

Correspondence to: E. Veldkamp (eveldka@gwdg.de)

Received: 6 May 2015 - Published in Biogeosciences Discuss.: 19 June 2015

Revised: 14 September 2015 - Accepted: 22 September 2015 - Published: 13 October 2015

\begin{abstract}
Expansion of palm oil and rubber production, for which global demand is increasing, causes rapid deforestation in Sumatra, Indonesia, and is expected to continue in the next decades. Our study aimed to (1) quantify changes in soil $\mathrm{CO}_{2}$ and $\mathrm{CH}_{4}$ fluxes with land-use change and (2) determine their controlling factors. In Jambi Province, Sumatra, we selected two landscapes on heavily weathered soils that differ mainly in texture: loam and clay Acrisol soils. In each landscape, we investigated the reference land-use types (forest and secondary forest with regenerating rubber) and the converted land-use types (rubber, 7-17 years old, and oil palm plantations, 9-16 years old). We measured soil $\mathrm{CO}_{2}$ and $\mathrm{CH}_{4}$ fluxes monthly from December 2012 to December 2013. Annual soil $\mathrm{CO}_{2}$ fluxes from the reference land-use types were correlated with soil fertility: low extractable phosphorus $(\mathrm{P})$ coincided with high annual $\mathrm{CO}_{2}$ fluxes from the loam Acrisol soil that had lower fertility than the clay Acrisol soil $(P<$ 0.05). Soil $\mathrm{CO}_{2}$ fluxes from the oil palm (107.2 to $115.7 \mathrm{mg}$ $\mathrm{C} \mathrm{m}^{-2} \mathrm{~h}^{-1}$ ) decreased compared to the other land-use types (between 178.7 and $195.9 \mathrm{mg} \mathrm{C} \mathrm{m}^{-2} \mathrm{~h}^{-1} ; P<0.01$ ). Across land-use types, annual $\mathrm{CO}_{2}$ fluxes were positively correlated with soil organic carbon (C) and negatively correlated with ${ }^{15} \mathrm{~N}$ signatures, extractable $\mathrm{P}$ and base saturation. This suggests that the reduced soil $\mathrm{CO}_{2}$ fluxes from oil palm were the result of strongly decomposed soil organic matter and reduced soil $\mathrm{C}$ stocks due to reduced litter input as well as
\end{abstract}

being due to a possible reduction in $\mathrm{C}$ allocation to roots due to improved soil fertility from liming and $\mathrm{P}$ fertilization in these plantations. Soil $\mathrm{CH}_{4}$ uptake in the reference landuse types was negatively correlated with net nitrogen $(\mathrm{N})$ mineralization and soil mineral $\mathrm{N}$, suggesting $\mathrm{N}$ limitation of $\mathrm{CH}_{4}$ uptake, and positively correlated with exchangeable aluminum (Al), indicating a decrease in methanotrophic activity at high $\mathrm{Al}$ saturation. Reduction in soil $\mathrm{CH}_{4}$ uptake in the converted land-use types (ranging from -3.0 to $-14.9 \mu \mathrm{g}$ $\mathrm{C} \mathrm{m}^{-2} \mathrm{~h}^{-1}$ ) compared to the reference land-use types (ranging from -20.8 to $-40.3 \mu \mathrm{g} \mathrm{C} \mathrm{m}{ }^{-2} \mathrm{~h}^{-1} ; P<0.01$ ) was due to a decrease in soil $\mathrm{N}$ availability in the converted land-use types. Our study shows for the first time that differences in soil fertility control the soil-atmosphere exchange of $\mathrm{CO}_{2}$ and $\mathrm{CH}_{4}$ in a tropical landscape, a mechanism that we were able to detect by conducting this study on the landscape scale.

\section{Introduction}

Oil palm (Elaeis guineensis) and rubber (Hevea brasiliensis) are two of the fastest-expanding tree cash crops in the tropics (Clay, 2013). Global oil palm production has quintupled from 1990 to 2013 and is currently grown on an estimated area of 17 million hectare (Mha) (Food and Agricultural Organiza- 
tion, 2014). Indonesia contributes nearly half of the global palm oil production (Food and Agricultural Organization, 2014) and is planning to double its production in the coming decade (Carlson et al., 2013). Similarly, rubber is grown on around 10 Mha globally, and Indonesia is the second largest rubber producer (Food and Agricultural Organization, 2014). Most Indonesian oil palm and rubber production is located in Sumatra (Indonesian Ministry of Agriculture, 2014), where the conversion of lowland rainforest to plantations has been widespread (Laumonier et al., 2010). It has been estimated that plantation establishment has caused a loss of $7.5 \mathrm{Mha}$ of Sumatran natural forest in the last 2 decades (1990-2010) (Margono et al., 2012), and future expansion will probably be at the expense of large areas of tropical forest, unless a properly planned and spatially explicit development strategy is implemented (Koh and Ghazoul, 2010).

Although the majority of remaining lowland tropical forests are located on nutrient-poor, heavily weathered soils, these ecosystems are among the most productive worldwide and contain globally significant above- and belowground carbon stocks. The high ecosystem productivity is possible despite the nutrient-poor soils because of efficient cycling of rock-derived nutrients (phosphorus $(\mathrm{P})$ and base cations) between vegetation and soil and also high soil nitrogen $(\mathrm{N})$ availability caused by biological $\mathrm{N}$ fixation (Hedin et al., 2009). Conversion of tropical forest to agricultural land-use systems does not only decrease biodiversity and contribute to climate change (Danielsen et al., 2009) but also alters soil fertility and soil physical properties in the newly established land-use systems (Dechert et al., 2004; Klinge et al., 2004). Burning of slashed vegetation is typically part of forest conversion, releasing large amounts of nutrients previously bound in the vegetation. A considerable part of these nutrients ends up in the soil but is susceptible to losses (through leaching and gaseous emission), which are especially high in the earlier years of crop establishment and decrease with time (Klinge et al., 2004). Furthermore, forest conversion is often associated with increases in soil bulk density. These dynamic changes in soil fertility and soil bulk density following forest conversion do not only affect agricultural production but also the soil-atmosphere exchange of trace gases like carbon dioxide $\left(\mathrm{CO}_{2}\right)$ and methane $\left(\mathrm{CH}_{4}\right)$ since their production, consumption and exchange are directly related to soil fertility and soil bulk density (Keller et al., 1993; Veldkamp et al., 2008).

Globally, soils are the largest natural source of $\mathrm{CO}_{2}$ (IPCC, 2007), which is released during respiration processes of microbial communities and roots (Raich and Schlesinger, 1992). While the important proximal controllers of soil $\mathrm{CO}_{2}$ fluxes are soil temperature and moisture, it has been demonstrated that other distal regulators such as vegetation type and soil physical and biochemical properties (e.g., bulk density, texture, $\mathrm{pH}$, carbon stocks) also affect soil $\mathrm{CO}_{2}$ fluxes (Raich and Schlesinger, 1992). Soils also play a dominant role in the production and consumption of $\mathrm{CH}_{4}$, a greenhouse gas with a global warming potential 23 times that of $\mathrm{CO}_{2}$ over a 100-year time period (IPCC, 2007). In soils, $\mathrm{CH}_{4}$ can be produced during anaerobic decomposition by methanogenic archaea, while $\mathrm{CH}_{4}$ can also be consumed by methanotrophic bacteria which are able to utilize $\mathrm{CH}_{4}$ as an energy source. Whether net consumption or net emission of $\mathrm{CH}_{4}$ occurs at the soil surface depends on the balance between production and consumption in the soil. For soil $\mathrm{CH}_{4}$ fluxes, the proximal controllers are soil moisture, gas diffusivity and temperature, while other distal regulators include microbial activity, $\mathrm{N}$ availability and aluminum toxicity (Verchot et al., 2000; Tamai et al., 2003; Bodelier and Laanbroek, 2004; Veldkamp et al., 2013).

In tropical lowland forest landscapes with heavily weathered soils, much of the spatial variability in trace gas fluxes appears to be related to soil texture (Sotta et al., 2006). In the Brazilian Amazon, lowland forests on Acrisol and Ferralsol soils display high soil $\mathrm{CO}_{2}$ emissions with large variations among sites that relate to soil texture: soils with sandy loam to sandy clay loam texture had $21-36 \%$ higher $\mathrm{CO}_{2}$ emissions than soils with clay texture (Keller et al., 2005; Sotta et al., 2006). Moreover, although well-drained soils in tropical lowland forests generally act as a sink for $\mathrm{CH}_{4}$ (Keller and Reiners, 1994; Verchot et al., 2000; Veldkamp et al., 2013), their differences in $\mathrm{CH}_{4}$ uptake are explicable by their differences in soil texture. In a review of 16 tropical lowland forests, the only factor correlating annual $\mathrm{CH}_{4}$ fluxes with site characteristics was a significant positive correlation with clay contents, indicating that the higher the clay content the lower the $\mathrm{CH}_{4}$ uptake (Veldkamp et al., 2013).

Since much of the original forest in our study area have been converted to oil palm and rubber plantations, the management practices in these land-use types added important factors that influence soil $\mathrm{CO}_{2}$ and $\mathrm{CH}_{4}$ fluxes from these converted landscapes. Earlier studies have shown that forest conversion to agricultural land-use types in the tropics lead to considerable changes in soil $\mathrm{CO}_{2}$ fluxes, which were related to changes in belowground $\mathrm{C}$ allocation (Davidson et al., 2000; Salimon et al., 2004), carbon quality (Werner et al., 2006), living fine-root biomass and litter input (Ishizuka et al., 2002; Sheng et al., 2010). Conversion of tropical forest to agricultural land use causes a reduction in soil $\mathrm{CH}_{4}$ uptake or even turns the soil into a source of $\mathrm{CH}_{4}$. Often this trend is explained by soil compaction, which leads to reduced gas diffusivity and accordingly limits aerobic $\mathrm{CH}_{4}$ oxidation while enhancing anaerobic $\mathrm{CH}_{4}$ production (Keller et al., 1993; Veldkamp et al., 2008). Changes in $\mathrm{N}$ availability may also play a role since $\mathrm{CH}_{4}$ uptake may be $\mathrm{N}$ limited (Bodelier and Laanbroek, 2004; Veldkamp et al., 2013) and high concentrations of ammonium $\left(\mathrm{NH}_{4}^{+}\right.$, e.g., from fertilization) can inhibit $\mathrm{CH}_{4}$ oxidation (Veldkamp et al., 2001; Werner et al., 2006). Finally, termites are known to produce $\mathrm{CH}_{4}$, and their presence may also affect the balance between production and consumption of $\mathrm{CH}_{4}$ (Seiler et al., 1984). 
Although Sumatra, Indonesia, represents a hot spot of land-use change, especially for the establishment of rubber and oil palm plantations, how this affects soil $\mathrm{CO}_{2}$ and $\mathrm{CH}_{4}$ fluxes remains highly uncertain for the following reasons: (1) most studies relating land-use change to trace gas emissions have been conducted in South and Central America (Keller and Reiners, 1994; Davidson et al., 2000; Verchot et al., 2000; Veldkamp et al., 2001; Salimon et al., 2004) and only few studies were conducted in southeast Asia (Ishizuka et al., 2002; Veldkamp et al., 2008); (2) most studies have focused on forest conversion to traditional land-use types, such as maize, pastures, slash-and-burn agriculture, cacao and coffee, and less on the rapidly expanding tree cash crops such as rubber and oil palm; (3) the few studies that reported $\mathrm{CO}_{2}$ and $\mathrm{CH}_{4}$ fluxes from oil palm plantations were conducted on peat soils (Melling et al., 2005a, b), whereas the studies conducted on mineral soils, where most of the rubber and oil palm plantations are located, were either conducted without spatial replication, covered only short periods of measurements (Ishizuka et al., 2002; Adachi et al., 2005; Werner et al., 2006) or measured only once (Ishizuka et al., 2005). It is imperative that better information becomes available on trace gas fluxes from these economically important and rapidly expanding rubber and oil palm plantations. Whether palmoil-based biofuel does indeed have environmental advantages compared to fossil fuel depends, among many factors, on the greenhouse gas balance during oil palm fruit production.

In the present study, our aims were to (1) quantify changes in soil-atmosphere fluxes of $\mathrm{CO}_{2}$ and $\mathrm{CH}_{4}$ with land-use change and (2) determine their controlling factors in a converted lowland landscape in Sumatra, Indonesia. Soilatmosphere fluxes of $\mathrm{CO}_{2}$ and $\mathrm{CH}_{4}$ were measured in forest and secondary forest with regenerating rubber (hereafter called jungle rubber, which is a more traditional rubber agroforestry system; Gouyon et al., 1993) as reference land-use types and the converted land-use types of monoculture rubber and oil palm plantations. Our study was designed to cover these four land-use types in each of the two landscapes on highly weathered soils that differed mainly in texture: clay and loam Acrisol soils. We tested the following hypotheses: (1) soil $\mathrm{CO}_{2}$ emissions and $\mathrm{CH}_{4}$ uptake will be higher in loam than in clay Acrisol soils, and (2) soil $\mathrm{CO}_{2}$ fluxes and $\mathrm{CH}_{4}$ uptake rates will be higher in the reference land-use types (forest and jungle rubber) than in the converted landuse types (rubber and oil palm plantations). Here, we present the first spatially replicated study with a full year of measurements that investigates soil $\mathrm{CO}_{2}$ and $\mathrm{CH}_{4}$ fluxes from conversion of forest or jungle rubber to rubber and oil palm plantations on mineral soils. We also evaluate the effect of management intensity since we compare rubber plantations without fertilizer inputs with fertilized oil palm plantations. Our results will be a critical contribution to trace gas lifecycle assessment of rubber and palm oil at the production stage.

\section{Material and methods}

\subsection{Study area and experimental design}

The study area is located in the lowlands (35-95 $\mathrm{m}$ above sea level) of Jambi province, Sumatra, Indonesia. In the past 2 decades, forest cover in Jambi province decreased by $1.14 \mathrm{Mha}$, which was about $40 \%$ of the forest cover in 1990 (Margono et al., 2012). The climate is humid tropical with a mean annual air temperature of $26.7 \pm 0.1^{\circ} \mathrm{C}$ and a mean annual precipitation of $2235 \pm 385 \mathrm{~mm}$ (1991-2011; data relating to Jambi Sultan Thaha Airport from the Indonesian Meteorological, Climatological and Geophysical Agency). The dry season is usually from May to September and the rainy season occurs from October to April. In 2013, during our study period, the wet season lasted slightly longer, while a drier period was detected between mid-June and the end of October. During this dry period, rainfall was reduced by $35-$ $57 \%$ compared to the wetter months during which rainfall was 333-362 mm per month.

We selected two landscapes on heavily weathered soils that differed mainly in texture: loam Acrisol soil $(36 \pm 6 \%$ sand, $32 \pm 4 \%$ silt and $32 \pm 2 \%$ clay in the top $0.5 \mathrm{~m}$ ) and clay Acrisol soil $(26 \pm 6 \%$ sand, $29 \pm 3 \%$ silt and $45 \pm 4 \%$ clay in the top $0.5 \mathrm{~m}$ ). This textural difference led to differences in soil fertility: forest sites in the clay Acrisol soil had a higher base saturation, Bray-extractable $\mathrm{P}$ and lower $\mathrm{Al}$ saturation compared to those in the loam Acrisol soil $(P \leq 0.01$ to 0.04; Appendix Table A1; Allen et al., 2015). Detailed soil physical and biochemical characteristics from our study sites were measured by Allen et al. (2015) and are summarized in Table A1. Acrisol soils cover about $50 \%$ of the land area in Sumatra and about one third of Indonesia (FAO et al., 2009). The clay Acrisol landscape was located about $160 \mathrm{~km}$ southwest of Jambi City between $01.94^{\circ} \mathrm{S}, 102.58^{\circ} \mathrm{E}$ and $02.14^{\circ} \mathrm{S}, 102.85^{\circ} \mathrm{E}$. Forest sites in this landscape were established within the Bukit Duabelas National Park (administered by the Ministry of Forestry, PHKA). The loam Acrisol landscape was located about $80 \mathrm{~km}$ southwest of Jambi City between $01.79^{\circ} \mathrm{S}, 103.24^{\circ} \mathrm{E}$ and $2.19^{\circ} \mathrm{S}, 103.36^{\circ} \mathrm{E}$. The forest sites in this landscape were established within the Harapan Forest Reserve and had been partially logged in the past (administered by the Restoration Ecosystem Indonesia Harapan, PT REKI).

In each landscape, we studied four land-use types: lowland forest, jungle rubber, and smallholder monoculture plantations of rubber and oil palm. In Jambi province, the smallholder rubber and oil palm plantations were established after clearing and burning either the forest (often partially logged) or jungle rubber (based on interviews conducted by Euler et al.; unpublished data). Thus, in our study the lowland forest and jungle rubber served as the reference land-use types, representing the baseline conditions with which we compared the rubber and oil palm plantations. 
For each of the four land-use types within each landscape, we selected four replicate plots $(50 \mathrm{~m} \times 50 \mathrm{~m}$ each with a minimum distance of $200 \mathrm{~m}$ between plots), totalling 32 plots that were all located on relatively flat, well-drained positions in the landscape. Additional information on tree species composition, tree density, tree height, basal area, and plantation age of these plots is reported in Table A2. Within each plot, we established a $10 \times 10$ grid which was used to select four randomly nested subplots $(5 \mathrm{~m} \times 5 \mathrm{~m}$ each $)$ that were at least $5 \mathrm{~m}$ from the plot's border. In each subplot, we placed one permanent chamber base at random to measure soil trace gas fluxes.

This approach of comparing soil $\mathrm{CO}_{2}$ and $\mathrm{CH}_{4}$ fluxes from the converted land-use types to that from the reference landuse types in order to assess the effects of land-cover change has the implicit assumption that before land-use conversion, soil characteristics were comparable. We tested this assumption by comparing the land-use-independent soil characteristics, i.e., clay content in $0.50-2.00 \mathrm{~m}$ depth, among land-use types within each landscape. Since there were no significant differences in clay contents between the reference and converted land-use types at these depths (Table A1; Allen et al., 2015), we deduced that the sites within each landscape had previously similar soil characteristics and that differences in trace gas fluxes can be attributed to the changes in land-use type and its associated management practices.

Since all the plantations were managed by smallholders, management practices of rubber and oil palm were diverse. The following information on management practices was based on our interviews of the smallholders. In 2013, oil palm and rubber plantations were weeded once or twice a year either manually or using herbicide (most commonly 2 $5 \mathrm{~L}$ Gramaxone ${ }^{\circledR}$ or Roundup ${ }^{\circledR} \mathrm{ha}^{-1} \mathrm{yr}^{-1}$ ). Oil palm plantations were fertilized, whereas rubber plantations were not. Oil palm plantations in the clay Acrisol landscape were fertilized only once during the rainy season, whereas those in the loam Acrisol landscape had a second fertilizer application in the dry season. The most commonly used fertilizers were NPK complete fertilizer (i.e., Phonska, Mahkota), potassium chloride $(\mathrm{KCl})$ and urea. Plantations fertilized once received about $300 \mathrm{~kg}$ NPK fertilizer ha ${ }^{-1} \mathrm{yr}^{-1}$ and plantations fertilized twice received about $550 \mathrm{~kg}$ NPK fertilizer ha ${ }^{-1} \mathrm{yr}^{-1}$. In terms of nutrient elements added, these rates were equivalent to $48-88 \mathrm{~kg} \mathrm{Nha}^{-1} \mathrm{yr}^{-1}, 21-38 \mathrm{~kg} \mathrm{Pha}^{-1} \mathrm{yr}^{-1}$ and $40-73 \mathrm{~kg} \mathrm{~K} \mathrm{ha}^{-1} \mathrm{yr}^{-1}$. Additionally, three of the smallholders applied 157 and $143 \mathrm{~kg} \mathrm{KCl}-\mathrm{K} \mathrm{ha}^{-1} \mathrm{yr}^{-1}$ and two of the smallholders applied $138 \mathrm{~kg}$ urea-N ha ${ }^{-1} \mathrm{yr}^{-1}$. One of the smallholders also applied lime in 2013 at about $200 \mathrm{~kg}$ dolomite $\mathrm{ha}^{-1} \mathrm{yr}^{-1}$. Smallholders typically applied the fertilizer around the oil palm tree at about $0.8-1 \mathrm{~m}$ distance from the tree base. Additionally, senescing fronds were regularly cut and piled on the interrows of an oil palm plantation, typically in the middle of the $9 \mathrm{~m}$ distance between rows of oil palms. Oil palm fruits were harvested every 2 weeks, whereas the latex of the rubber and jungle rubber was collected weekly.

In addition to the monthly flux measurements conducted at the smallholder farms described above, we simulated fertilizations and conducted more frequent measurements ( 6 to 11 times) during 3 to 8 weeks following fertilization as the monthly sampling may have missed the short-term effect of fertilization on soil $\mathrm{CO}_{2}$ and $\mathrm{CH}_{4}$ fluxes. We chose three plots of oil palm plantations in each of the two landscapes, and in each plot we selected three trees separated by an interrow distance of $9 \mathrm{~m}$ (in total, 18 oil palm trees). At $0.8 \mathrm{~m}$ distance from the base of each tree, we applied the fertilizer manually to the area within $0.2 \mathrm{~m}$ around the tree using the same rate that smallholders applied to these oil palm plantations (i.e., equivalent to $2 \mathrm{~kg}$ fertilizer per tree, based on $300 \mathrm{~kg}$ NPK fertilizer ha ${ }^{-1}$ divided by $134-140$ trees ha $^{-1}$; Table A2). We used the same fertilizer forms that smallholders applied, i.e., NPK complete fertilizer in the clay Acrisol landscape and a combination of $\mathrm{KCl}$, ammonium sulfate and NPK complete fertilizer in the loam Acrisol landscape. One chamber base was placed at $0.3 \mathrm{~m}$ distance from the tree base (chamber location a); another chamber base, to which fertilizer was applied, was placed at $0.8 \mathrm{~m}$ distance from the tree (chamber location b); and a third chamber was placed at $4-4.5 \mathrm{~m}$ distance from the tree and served as a reference chamber without direct fertilizer application (chamber location c). In the clay Acrisol landscape, measurements in the three oil palm plots were done from mid-October to midDecember 2013, mid-February to mid-March 2014, and midFebruary to mid-April 2013. In the loam Acrisol landscape, measurements were done from the end of October 2013 to mid-December 2013, mid-January to mid-March 2014, and mid-March to the start of April 2014. Shorter intervals of sampling days (Appendix Fig. B1) were conducted right after the fertilizer application.

\section{$2.2 \mathrm{CO}_{2}$ and $\mathrm{CH}_{4}$ flux measurement}

Soil $\mathrm{CO}_{2}$ and $\mathrm{CH}_{4}$ fluxes were measured monthly from December 2012 to December 2013, using static vented chambers. We are aware that the use of static vented chambers for $\mathrm{CO}_{2}$ and $\mathrm{CH}_{4}$ flux measurements could have possible sources of error due to changes in diffusion gradients during chamber closure. We have however adapted the design of our chambers and the flux calculation to minimize, if not avoid, these possible errors (see below). A clear advantage of the static vented chamber method compared to other methods is that it remains the only operational method that can be used to measure trace gas fluxes at a large number of plots (in our case 32) spread over a large area with regular measurements within a year. Furthermore, it also yields information on short-distance spatial variability of trace gas fluxes, which cannot be quantified by more integrative tower-based methods. Our chamber bases were made of polyvinyl chloride $\left(0.05 \mathrm{~m}^{2}\right.$ area) and inserted $\sim 0.03 \mathrm{~m}$ into the soil. We 
placed a permanent chamber base at random in each of the four subplots per replicate plot 1 month before the first measurement started. Since the area occupied by piled fronds or applied with fertilizer in oil palm plantations was relatively small, none of these randomly placed chamber bases (range of distance to the tree base was 1.8-5 m) happened to be located in such an area. During sampling, the chamber bases were covered with polyethylene hoods $(0.27 \mathrm{~m}$ total chamber height and $12 \mathrm{~L}$ total volume) equipped with a Luer-lock sampling port and a vent for pressure equilibrium. Four gas samples (30 mL each) were removed at 1, 11, 21 and 31 min after chamber closure using a plastic syringe connected to the Luer-lock port. Immediately after sampling, gas samples were stored with overpressure in pre-evacuated 12 mL Labco Exetainers ${ }^{\circledR}$ (Labco Limited, Lampeter, UK) with rubber septa that were only used once. Our group has tested these exetainers for an extended period of sample storage (e.g., up to 6 months) and air transport by storing and transporting standard gases of known concentrations in overpressure, and these exetainers were proven to be leak proof. Gas samples in exetainers were transported to Germany by air every 3-4 months and were analyzed upon arrival using a gas chromatograph (GC 6000 Vega Series 2, Carlo Erba Instruments, Milan, Italy, with an ASPEC autosampler, Gilson SAS, Villiers, Le Bel, France), equipped with a flame ionization detector and an electron capture detector. Three standard gases were used for calibration with concentrations from 350 to $5000 \mathrm{ppm}$ for $\mathrm{CO}_{2}$ and 1000 to $5000 \mathrm{ppb}$ for $\mathrm{CH}_{4}$ (Deuste Steininger $\mathrm{GmbH}$, Mühlhausen, Germany). The software Probe66 version 1.3 (Messwert GmbH, Göttingen, Germany) was used to determine $\mathrm{CH}_{4}$ and $\mathrm{CO}_{2}$ sample concentrations by comparing integrated peak areas with those of the standard gases. Fluxes were calculated from the concentration change over the duration of chamber closure and adjusted with actual air temperature and pressure measured at the time of sampling. The linearity of increase in $\mathrm{CO}_{2}$ concentrations with the duration of chamber closure $\left(R^{2} \geq 0.98\right)$ was checked for each chamber measurement, and in a few cases where concentration curved at the last sampling time, we excluded the last data point and calculated the fluxes based on the linear increase in concentrations during the first three samplings. The majority of the measurements showed a linear change in $\mathrm{CH}_{4}$ concentrations with the duration of chamber closure. There were a few measurements when changes in $\mathrm{CH}_{4}$ concentrations with time of chamber closure were small, mostly when net $\mathrm{CH}_{4}$ uptake was low; in such cases, the calculated $\mathrm{CH}_{4}$ flux using linear regression was not significantly different from 0 . These fluxes were, however, retained in the statistical analyses to avoid bias by excluding low $\mathrm{CH}_{4}$ fluxes or by assuming that these fluxes were 0. Assuming constant flux rates per day, annual soil $\mathrm{CO}_{2}$ and $\mathrm{CH}_{4}$ fluxes from the monthly sampling and total fluxes during a fertilization event (see below) were calculated by adopting the trapezoidal rule on time intervals between measured flux rates, similar to the method we em- ployed in our earlier studies (e.g., Koehler et al., 2009; Veldkamp et al., 2013)

\subsection{Auxiliary measurements}

Soil temperature, moisture and mineral $\mathrm{N}$ content were measured with each trace gas measurement. Soil temperature was determined in the top $0.05 \mathrm{~m}$ depth using a GMH 1170 digital thermometer (Greisinger electronic $\mathrm{GmbH}$, Regenstauf, Germany). Soil samples for mineral N content were also taken from the top $0.05 \mathrm{~m}$ at approximately $1 \mathrm{~m}$ distance from each chamber with four soil samples per plot. These four soil samples were pooled to represent each replicate plot on each day of measurement, and roots, leaves and twigs were manually removed. For the fertilization experiment, soil samples taken near each chamber location (a, b and c) were processed separately. Since even short storage of disturbed soil samples can affect mineral $\mathrm{N}$ concentrations (Arnold et al., 2008), extraction was done in the field immediately following soil sampling. A soil sample was added to a prepared $250 \mathrm{~mL}$ plastic bottle containing $150 \mathrm{~mL}$ of $0.5 \mathrm{~mol} \mathrm{~L}^{-1} \mathrm{~K}_{2} \mathrm{SO}_{4}$ (approximately $1: 3$ ratio of fresh soil to extractant volume) and transported to the field station. At the field station, samples were shaken for $1 \mathrm{~h}$, filtered through prewashed (with $0.5 \mathrm{~mol} \mathrm{~L}^{-1} \mathrm{~K}_{2} \mathrm{SO}_{4}$ ) filter papers (Whatman, GE Healthcare Life Sciences, $4 \mu \mathrm{m}$ nominal pore size), and the filtrate was immediately stored in a freezer. The remaining field-moist soil samples were stored in plastic bags and gravimetric moisture content was determined at the field station, for which 50-100 g of fresh soil was dried at $105^{\circ} \mathrm{C}$ for at least 1 day. The gravimetric moisture content was used to calculate the dry mass of the soil extracted for mineral $\mathrm{N}$. Frozen extracts were transported by air to Germany to ensure that they stayed frozen throughout the transport until analysis. At our laboratory at the University of Göttingen, Germany, $\mathrm{NH}_{4}^{+}$and $\mathrm{NO}_{3}^{-}$concentrations in the extracts were analyzed using continuous flow injection colorimetry (SEAL Analytical AA3, SEAL Analytical GmbH, Norderstedt, Germany). $\mathrm{NH}_{4}^{+}$was determined by salicylate and dicloroisocyanuric acid reaction (Autoanalyzer Method G-102-93), and $\mathrm{NO}_{3}^{-}$was determined by the cadmium reduction method with an $\mathrm{NH}_{4} \mathrm{Cl}$ buffer (Autoanalyzer Method G-254-02). Soil water content was expressed as water-filled pore space (WFPS), calculated using a particle density of $2.65 \mathrm{~g} \mathrm{~cm}^{-3}$ for mineral soil and the measured bulk densities at our study sites (Table A1).

\subsection{Statistical analysis}

All statistical analyses of the monthly measurements of soil $\mathrm{CO}_{2}$ and $\mathrm{CH}_{4}$ fluxes were conducted using the means of the four chambers (or subplots) that represent each replicate plot on a given sampling day. Data were checked for normal distribution (using Shapiro-Wilk tests), and if necessary, a logarithmic (for $\mathrm{CO}_{2}, \mathrm{CH}_{4}$, and mineral $\mathrm{N}$ ) or square 
root (for WFPS) transformation was used. For our first objective, we conducted comparisons of the reference land-use types between the two landscapes in order to test the first hypothesis. Then we carried out comparisons among land-use types within each landscape to test our second hypotheses. Linear mixed-effect models (LMEs) were applied (Crawley, 2009) with either landscape (i.e., comparing landscapes for each reference land use) or land use (i.e., comparing land-use types within each landscape) as the fixed effect and replicate plots and sampling days as the random effects. For the fertilization experiment, we tested differences in soil $\mathrm{CO}_{2}$ and $\mathrm{CH}_{4}$ fluxes between chamber locations within each oil palm plantation plot, using LMEs with chamber location as the fixed effect and palm trees and sampling days as the random effects. We extended the LME model to include either (1) a variance function that allows different variances of the fixed effect and/or (2) a first-order temporal autoregressive process, which assumes that correlation between measurements decreases with increasing time difference if this improved the relative goodness of the model fit based on the Akaike information criterion. Fixed effect was considered significant based on the analysis of variance at $P \leq 0.05$, and differences between landscapes or land-use types (or chamber locations for the fertilization experiment) were assessed using Fisher's least significant difference (LSD) test $(P \leq 0.05)$. For our second objective, we assess how soil factors influence the seasonal variations in soil $\mathrm{CO}_{2}$ and $\mathrm{CH}_{4}$ fluxes, using Pearson's correlation tests with soil temperature, WFPS, $\mathrm{NO}_{3}^{-}, \mathrm{NH}_{4}^{+}$and total mineral $\mathrm{N}$. This assessment of seasonal controls of trace gas fluxes was conducted for each land use type within each landscape using the means of the four replicate plots (as spatial representation) on each of the 12 monthly measurements in order to focus the analysis on temporal variation. Lastly, we assessed the influence of soil physical and biochemical characteristics (Table A1) on the spatial variations in soil annual $\mathrm{CO}_{2}$ and $\mathrm{CH}_{4}$ fluxes first on the reference land-use types across landscapes (16 plots) and second across land-use types within each landscape (16 plots), using Spearman's rank correlation test. The first was to assess the spatial controls of trace gas fluxes from the reference land-use types, and the second was to evaluate which soil factors drive the spatial variation in trace gas fluxes across landuse types. We used the annual fluxes as temporal representation in order to focus this analysis on the spatial variation. For all correlation tests, statistical significance was taken at $P \leq 0.05$, except in a few cases for which a marginal significance at $P \leq 0.09$ was considered because our experimental design encompassed the inherent spatial variability in the studied landscapes. All statistical analyses were conducted using R 3.0.2 (R Development Core Team, 2013).

\section{Results}

\subsection{Reference land-use types (forest and jungle rubber): comparison between landscapes}

WFPS in the jungle rubber was higher in the clay than loam Acrisol soils $(P<0.01)$, but, in the forest, WFPS did not differ between landscapes $(P=0.56$; Fig. 1a, b). In both landscapes, we detected lower WFPS during the drier period (mean WFPS ranged from 38 to $80 \%$ between mid-June and October) compared to the wetter period (mean WFPS ranged from 50 to $96 \%$; $P<0.01$; Fig. 1a, b). Soil temperatures in the forest were lower in the clay than loam Acrisol soils $(P=0.02$; Fig. $1 \mathrm{c}, \mathrm{d})$, which was probably due to the difference in the time of the day when measurements were conducted. Soil temperatures in the jungle rubber did not differ between landscapes $(P=0.17)$.

In both landscapes, $\mathrm{NH}_{4}^{+}$was the dominant form of mineral $\mathrm{N}$ (Table 1). Soil $\mathrm{NH}_{4}^{+}$contents in the jungle rubber were higher in the clay than in loam Acrisol soils $(P=0.02)$, but in the forest soil $\mathrm{NH}_{4}^{+}$contents did not differ between landscapes $(P=0.90$; Table 1$)$. Soil $\mathrm{NO}_{3}^{-}$contents in the forest were higher in the clay than in loam Acrisol soils $(P<0.01)$, whereas soil $\mathrm{NO}_{3}^{-}$contents in the jungle rubber were higher in the loam than in clay Acrisol soils $(P=0.02$; Table 1$)$. Total mineral $\mathrm{N}$ contents in both reference land-use types did not differ between landscapes ( $P=0.11-0.19$; Table 1$)$.

We detected no differences in soil $\mathrm{CO}_{2}$ fluxes between landscapes for the reference land-use types $(P=0.63-0.69$; Table 2; Fig. 2a, b). Similarly, soil $\mathrm{CH}_{4}$ fluxes from both reference land-use types were also comparable between the two landscapes ( $P=0.26-0.27$; Table 2; Fig. 2c, d). However, in the loam Acrisol soil, two of the four forest sites displayed net $\mathrm{CH}_{4}$ emissions in $26 \%$ of the measurements, which resulted in its largest variation among plots (as indicated by its largest standard error around the mean; Table 2).

\subsection{Converted land-use types (rubber and oil palm plantations): comparisons to the reference land-use types within each landscape}

While in both landscapes WFPS did not differ among landuse types ( $P=0.12-0.26$; Fig. 1a, b), soil temperatures were slightly higher in the plantations $\left(27.2 \pm 0.1{ }^{\circ} \mathrm{C}\right)$ compared to the reference land-use types $\left(25.9 \pm 0.1^{\circ} \mathrm{C}\right)$ in each landscape (both $P<0.01$; Fig. 1c, d). Soil $\mathrm{NH}_{4}^{+}$contents in rubber were lower than in all other land-use types in the clay Acrisol soil $(P=0.05)$, and soil $\mathrm{NH}_{4}^{+}$contents in both rubber and oil palm were also lower than in the reference landuse types in the loam Acrisol soil $(P=0.03$; Table 1). In the clay Acrisol soil, $\mathrm{NO}_{3}^{-}$contents in rubber and oil palm were lower than in forest $(P<0.01)$, and in the loam Acrisol soil $\mathrm{NO}_{3}^{-}$contents in rubber were lowest, whereas these were intermediary in oil palm $(P<0.01$; Table 1$)$. The latter was related to fertilizer application by the owner of one of the 

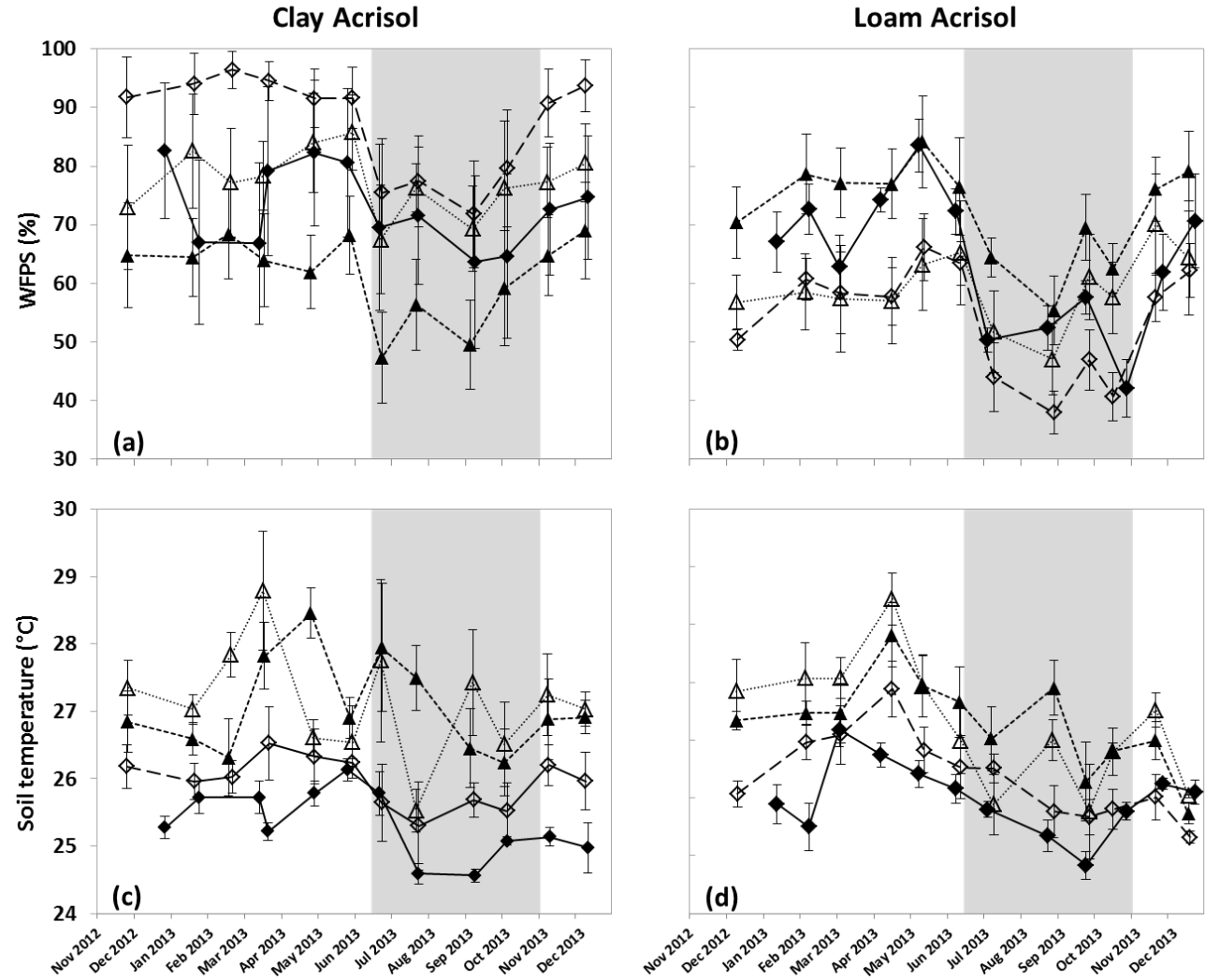

Figure 1. Mean $( \pm$ SE, $n=4)$ soil water-filled pore space (WFPS) and soil temperature in the top $0.05 \mathrm{~m}$ depth under forest $(\checkmark)$, jungle rubber $(\diamond)$, rubber $(\Delta)$ and oil palm $(\triangle)$ in the clay Acrisol soil (a and c) and the loam Acrisol soil (b and d) in Jambi, Sumatra, Indonesia, measured monthly from December 2012 to December 2013. Grey shadings mark the dry season.

Table 1. Mean $( \pm$ SE, $n=4)$ soil-extractable mineral nitrogen in the top $0.05 \mathrm{~m}$ depth for different land-use types within each soil landscape in Jambi, Sumatra, Indonesia, measured monthly from December 2012 to December 2013. Means followed by different lowercase letters indicate significant differences among land-use types within a soil landscape and different capital letters indicate significant differences between soil landscapes within a land-use type (linear mixed-effect models with Fisher's least significant difference (LSD) test at $P \leq 0.05$ ).

\begin{tabular}{|c|c|c|c|}
\hline Land-use type & $\begin{array}{l}\mathrm{NH}_{4}^{+} \\
\left(\mathrm{mgNkg}^{-1}\right)\end{array}$ & $\begin{array}{l}\mathrm{NO}_{3}^{-} \\
\left(\mathrm{mgNkg}^{-1}\right)\end{array}$ & $\begin{array}{l}\text { mineral } \mathrm{N} \\
\left(\mathrm{mgNkg}^{-1}\right)\end{array}$ \\
\hline \multicolumn{4}{|l|}{ clay Acrisol soil } \\
\hline Forest & $6.99 \pm 1.03^{\mathrm{a}, \mathrm{A}}$ & $2.15 \pm 0.36^{\mathrm{a}, \mathrm{A}}$ & $9.14 \pm 1.34^{\mathrm{a}, \mathrm{A}}$ \\
\hline Jungle rubber & $7.33 \pm 0.21^{\mathrm{a}, \mathrm{A}}$ & $0.23 \pm 0.06^{\mathrm{b}, \mathrm{B}}$ & $7.56 \pm 0.26^{\mathrm{b}, \mathrm{A}}$ \\
\hline Rubber & $4.25 \pm 0.23^{\mathrm{b}, \mathrm{A}}$ & $0.05 \pm 0.01^{\mathrm{b}, \mathrm{B}}$ & $4.30 \pm 0.23^{\mathrm{c}, \mathrm{A}}$ \\
\hline Oil palm & $5.80 \pm 0.64^{\mathrm{a}, \mathrm{A}}$ & $0.81 \pm 0.49^{\mathrm{b}, \mathrm{A}}$ & $6.60 \pm 0.42^{\mathrm{b}, \mathrm{A}}$ \\
\hline \multicolumn{4}{|c|}{ loam Acrisol soil } \\
\hline Forest & $5.94 \pm 0.40^{\mathrm{a}, \mathrm{A}}$ & $0.61 \pm 0.15^{\mathrm{ab}, \mathrm{B}}$ & $6.55 \pm 0.28^{\mathrm{a}, \mathrm{A}}$ \\
\hline Jungle rubber & $5.64 \pm 0.28^{\mathrm{a}, \mathrm{B}}$ & $1.25 \pm 0.63^{\mathrm{a}, \mathrm{A}}$ & $6.89 \pm 0.59^{\mathrm{a}, \mathrm{A}}$ \\
\hline Rubber & $4.14 \pm 0.57^{\mathrm{b}, \mathrm{A}}$ & $0.12 \pm 0.02^{\mathrm{b}, \mathrm{A}}$ & $4.26 \pm 0.58^{\mathrm{b}, \mathrm{A}}$ \\
\hline Oil palm & $4.20 \pm 1.10^{\mathrm{b}, \mathrm{B}}$ & $0.60 \pm 0.36^{\mathrm{ab}, \mathrm{B}}$ & $4.81 \pm 1.44^{\mathrm{b}, \mathrm{B}}$ \\
\hline
\end{tabular}

oil palm plots just a month prior to our measurement. Total mineral $\mathrm{N}$ showed similar differences among land-use types in each landscape to those for soil $\mathrm{NH}_{4}^{+}$and $\mathrm{NO}_{3}^{-}$contents (both $P<0.01$; Table 1).
Soil $\mathrm{CO}_{2}$ fluxes from oil palm were $45 \%$ lower in the clay Acrisol soil and $38 \%$ lower in the loam Acrisol soil compared to the forest (both $P<0.01$; Table 2; Fig. 2a, b). From the fertilization experiment, soil $\mathrm{CO}_{2}$ fluxes within $1 \mathrm{~m}$ of the 

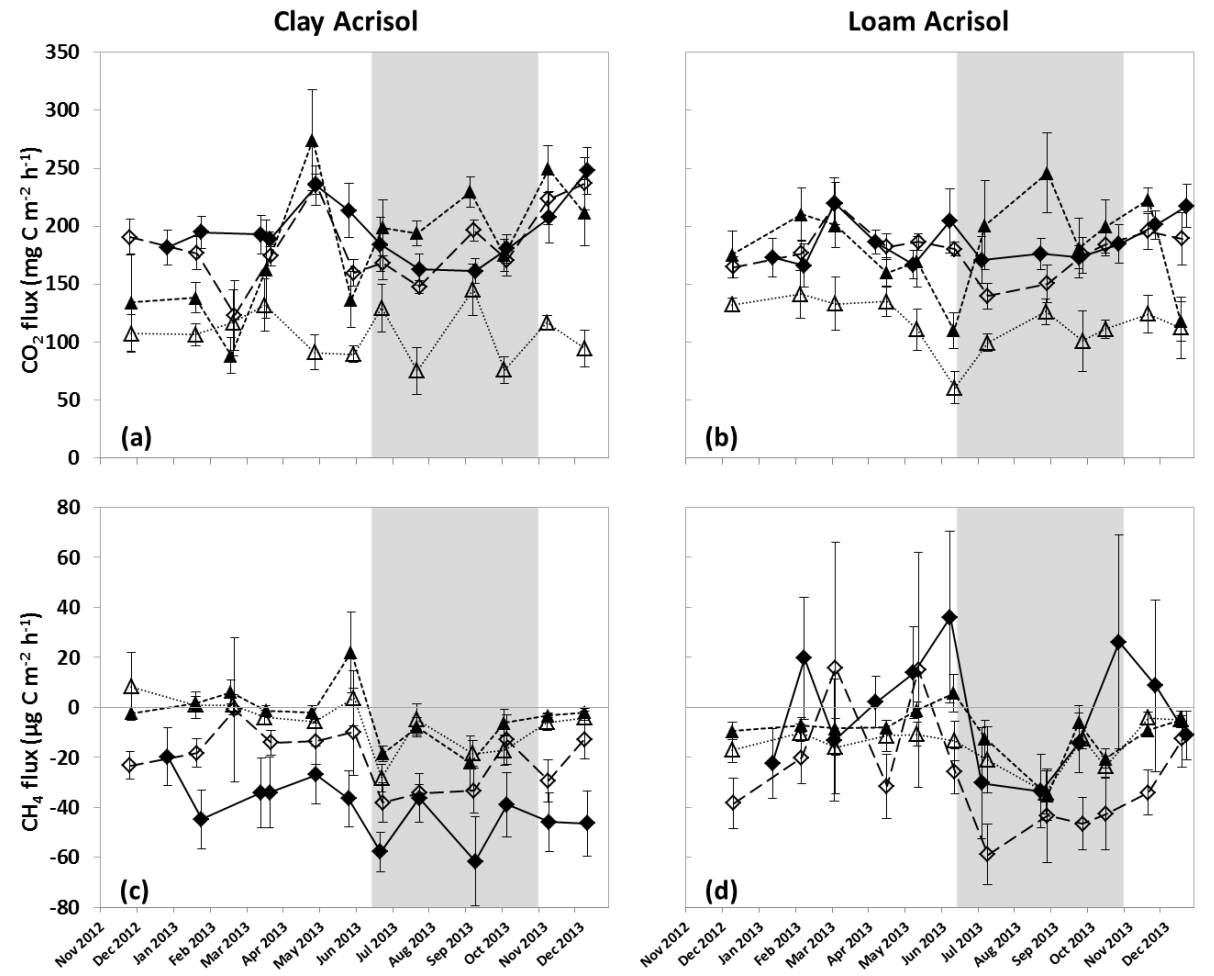

Figure 2. Mean $( \pm \mathrm{SE}, n=4)$ soil $\mathrm{CO}_{2}$ fluxes and soil $\mathrm{CH}_{4}$ fluxes from forest $(\diamond)$, jungle rubber $(\diamond)$, rubber $(\Delta)$ and oil palm $(\triangle)$ on the clay Acrisol soil (a and c) and the loam Acrisol soil (b and d) in Jambi, Sumatra, Indonesia, measured monthly from December 2012 to December 2013. Grey shadings mark the dry season.

Table 2. Mean $( \pm \mathrm{SE}, n=4)$ soil $\mathrm{CO}_{2}$ and $\mathrm{CH}_{4}$ fluxes and annual soil $\mathrm{CO}_{2}$ and $\mathrm{CH}_{4}$ fluxes from different land-use types within each soil landscape in Jambi, Sumatra, Indonesia, measured monthly from December 2012 to December 2013. Means followed by different lowercase letters indicate significant differences among land-use types within a soil landscape and different capital letters indicate significant differences between soil landscapes within a land-use type (linear mixed-effect models with Fisher's LSD test at $P \leq 0.05$ ). Annual soil CO 2 and $\mathrm{CH}_{4}$ fluxes were not statistically tested for differences between landscapes or land-use types since these annual values are trapezoidal extrapolations. For the loam Acrisol soil, $\mathrm{CH}_{4}$ fluxes in parenthesis included only the two forest sites that had a dominantly net $\mathrm{CH}_{4}$ uptake, and comparison among land-use types was conducted between jungle rubber, rubber and oil palm, which all showed net $\mathrm{CH}_{4}$ uptake.

\begin{tabular}{lllll}
\hline Land-use type & $\begin{array}{l}\mathrm{CO}_{2} \text { fluxes } \\
\left(\mathrm{mgC} \mathrm{m}^{-2} \mathrm{~h}^{-1}\right)\end{array}$ & $\begin{array}{l}\text { Annual } \mathrm{CO}_{2} \text { fluxes } \\
\left(\mathrm{MgCha}^{-1} \text { year }^{-1}\right)\end{array}$ & $\begin{array}{l}\mathrm{CH}_{4} \text { fluxes } \\
\left(\mu \mathrm{g} \mathrm{Cm}^{-2} \mathrm{~h}^{-1}\right)\end{array}$ & $\begin{array}{l}\text { Annual } \mathrm{CH}_{4} \text { fluxes } \\
\left(\mathrm{kgCha}^{-1} \text { year }^{-1}\right)\end{array}$ \\
\hline \multicolumn{1}{l}{ clay Acrisol soil } & & & \\
\hline Forest & $195.93 \pm 13.51^{\mathrm{a}, \mathrm{A}}$ & $16.93 \pm 1.19$ & $-40.3 \pm 10.25^{\mathrm{c}, \mathrm{A}}$ & $-3.63 \pm 0.89$ \\
Jungle rubber & $185.25 \pm 9.40^{\mathrm{a}, \mathrm{A}}$ & $16.11 \pm 0.72$ & $-20.79 \pm 7.24^{\mathrm{b}, \mathrm{A}}$ & $-1.85 \pm 0.59$ \\
Rubber & $182.77 \pm 16.22^{\mathrm{a}, \mathrm{A}}$ & $16.09 \pm 1.40$ & $-3.00 \pm 1.26^{\mathrm{a}, \mathrm{A}}$ & $-0.29 \pm 0.12$ \\
Oil palm & $107.24 \pm 7.23^{\mathrm{b}, \mathrm{A}}$ & $9.22 \pm 0.61$ & $-6.37 \pm 3.06^{\mathrm{a}, \mathrm{A}}$ & $-0.52 \pm 0.26$ \\
\hline \multicolumn{1}{l}{ loam Acrisol soil } & & & \\
\hline Forest & $186.64 \pm 13.72^{\mathrm{a}, \mathrm{A}}$ & $16.21 \pm 1.17$ & $-1.56 \pm 17.07^{\mathrm{A}}$ & $-0.18 \pm 1.55$ \\
& & & $(-29.45 \pm 11.92)$ & \\
Jungle rubber & $178.69 \pm 11.17^{\mathrm{a}, \mathrm{A}}$ & $15.55 \pm 0.94$ & $-26.92 \pm 3.85^{\mathrm{b}, \mathrm{A}}$ & $-2.42 \pm 0.34$ \\
Rubber & $182.86 \pm 14.47^{\mathrm{a}, \mathrm{A}}$ & $16.52 \pm 1.32$ & $-9.73 \pm 3.79^{\mathrm{a}, \mathrm{A}}$ & $-0.93 \pm 0.35$ \\
Oil palm & $115.74 \pm 10.99^{\mathrm{b}, \mathrm{A}}$ & $10.29 \pm 0.88$ & $-14.94 \pm 3.14^{\mathrm{a}, \mathrm{A}}$ & $-1.38 \pm 0.31$ \\
\hline
\end{tabular}

oil palm base (chamber locations a and $b$ ) were on average $2.3 \pm 0.2$ times higher than those $4-4.5 \mathrm{~m}$ from the tree base (chamber location c) in both landscapes (all $P<0.01$; Table A3). However, this area within $1 \mathrm{~m}$ distance to the tree 
base is only $3 \mathrm{~m}^{2}$ per tree or $4 \%$ on a hectare basis. Even if we were to include these elevated soil $\mathrm{CO}_{2}$ fluxes into annual estimates using area-weighted contributions, the high fluxes within $1 \mathrm{~m}$ distance to the tree base would account for less than the standard errors (7-9\%) of the mean annual fluxes.

Soil $\mathrm{CH}_{4}$ uptake in the plantations was $84 \%$ (oil palm) and $93 \%$ (rubber) lower compared to the forest and $69 \%$ (oil palm) and $86 \%$ (rubber) lower compared to the jungle rubber in the clay Acrisol soil ( $P<0.01$; Table 2; Fig. 2c, d). Also in the loam Acrisol soil, $\mathrm{CH}_{4}$ uptake in the plantations was lower (reduction of $64 \%$ for rubber and $44 \%$ for oil palm) compared to jungle rubber ( $P=0.02$; Table 2; Fig. 2c, d). However, $\mathrm{CH}_{4}$ uptake in the forest on loam Acrisol soils deviated from the differences detected in the clay Acrisol soils because of the two forest sites that displayed net $\mathrm{CH}_{4}$ emissions (see above; Table 2; Fig. 2d). From the fertilization experiment, soil $\mathrm{CH}_{4}$ uptake from the area of fertilizer application (chamber location b) was $2.6 \pm 0.2$ times lower than the unfertilized chamber locations a and $\mathrm{c}$ (respectively $0.3 \mathrm{~m}$ and $4-4.5 \mathrm{~m}$ from the oil palm base) $(P \leq 0.01-0.05$; Table A3), with the exception of plot 3 in the clay Acrisol soil $\left(P=0.45\right.$; Table A3). In most cases, $\mathrm{CH}_{4}$ uptake in chamber location $\mathrm{b}$ was reduced immediately following fertilizer application and was restored to prefertilization values after about 6 weeks (Fig. B1). Even if we included these reduced soil $\mathrm{CH}_{4}$ fluxes into annual estimates using area-weighted contributions, the low area coverage $(\sim 1.3 \%$ of $1 \mathrm{ha})$ and time duration ( $12 \%$ of 1 year) would render a negligible effect.

\subsection{Seasonal controls of $\mathrm{CO}_{2}$ and $\mathrm{CH}_{4}$ fluxes from each land-use type}

In the clay Acrisol soil, $\mathrm{CH}_{4}$ fluxes were positively correlated with WFPS (Table 3) in each of the four land-use types, signifying the higher $\mathrm{CH}_{4}$ uptake in the dry than in the wet season ( $P \leq 0.01-0.03$; Fig. $2 \mathrm{c})$. Soil $\mathrm{CH}_{4}$ fluxes correlated negatively with $\mathrm{NO}_{3}^{-}$contents in forest and with soil $\mathrm{CO}_{2}$ fluxes in rubber (Table 3). Across all land-use types, soil $\mathrm{CH}_{4}$ uptake was negatively correlated with total mineral $\mathrm{N}$ content ( $R=-0.47, P \leq 0.01, n=41$; Fig. 3a) and $\mathrm{NO}_{3}^{-}$content $(R=-0.73, P \leq 0.01, n=41)$. Some correlations in Table 3 were possibly spurious: in oil palm, soil $\mathrm{CO}_{2}$ fluxes were positively correlated with soil temperatures (Table 3 ) even if the temperate range was small $\left(25.5-28.8^{\circ} \mathrm{C}\right)$ such that this correlation was likely caused by the differences in sampling time during the day rather than by a seasonal temperature pattern. In jungle rubber, plotting soil $\mathrm{CO}_{2}$ fluxes against soil $\mathrm{NO}_{3}^{-}$contents showed that their correlation (Table 3) was apparently caused by a group of many low $\mathrm{NO}_{3}^{-}$contents against one high $\mathrm{NO}_{3}^{-}$value and this correlation became insignificant when the one high value was removed. Also, in rubber, the marginal negative correlation between soil $\mathrm{CH}_{4}$ fluxes with $\mathrm{NO}_{3}^{-}$contents was due to the correlation between WFPS and $\mathrm{NO}_{3}^{-}$contents.
In the loam Acrisol soil, seasonal variations in soil $\mathrm{CO}_{2}$ fluxes were positively correlated with WFPS in jungle rubber and negatively correlated with WFPS in rubber (Table 3). Some correlations in Table 3 were also spurious, caused by differences in sampling time during the day rather than by a seasonal pattern: correlation between soil $\mathrm{CO}_{2}$ fluxes and soil temperature in forest and oil palm despite narrow temperate ranges $\left(24.8-27.2^{\circ} \mathrm{C}\right.$ in forest and $25.8-29.4^{\circ} \mathrm{C}$ in oil palm). The negative correlation between soil $\mathrm{CO}_{2}$ fluxes and $\mathrm{NO}_{3}^{-}$contents in jungle rubber was driven by the negative correlation between WFPS and $\mathrm{NO}_{3}^{-}$(Table 3). As was observed in the clay Acrisol soil, seasonal variation in soil $\mathrm{CH}_{4}$ fluxes from the loam Acrisol soil was positively correlated with WFPS in each of the three land-use types (Table 3) with the exception of the forest which was caused by one extreme $\mathrm{CH}_{4}$ emission from a single chamber $\left(656.47 \mu \mathrm{g} \mathrm{C} \mathrm{m}^{-2} \mathrm{~h}^{-1}\right)$. When this one value was excluded, a positive correlation between soil $\mathrm{CH}_{4}$ fluxes and WFPS was also detected for forest $\left(R=0.60, P \leq 0.01, n=12\right.$ ). Soil $\mathrm{CH}_{4}$ fluxes also correlated positively with soil $\mathrm{CO}_{2}$ fluxes in jungle rubber, whereas this correlation was negative in rubber (Table 3 ). In the jungle rubber, soil $\mathrm{CH}_{4}$ fluxes correlated negatively with soil $\mathrm{NO}_{3}^{-}$contents (Table 3 ). Across land-use types, we also observed negative correlations of soil $\mathrm{CH}_{4}$ uptake with total mineral N content $(R=-0.52, P \leq 0.01, n=38$; Fig. $3 \mathrm{~b})$ and $\mathrm{NO}_{3}^{-}$content $(R=-0.75, P \leq 0.01, n=38)$.

\subsection{Spatial controls of annual $\mathrm{CO}_{2}$ and $\mathrm{CH}_{4}$ fluxes across land-use types within each landscape}

For these correlation analyses, we used all soil physical and biochemical characteristics which are reported in Table A1. Apart from the correlations reported here, there were no other significant correlations with any of the tested soil physical and biochemical characteristics. First, analyzing both reference land-use types (forest and jungle rubber) across landscapes, the only significant correlation between annual soil $\mathrm{CO}_{2}$ emissions and soil parameters was with sand content (Spearman's $\rho=-0.51, P=0.08, n=16$ ). However, analyzing for each landscape separately, annual soil $\mathrm{CO}_{2}$ fluxes from the reference land-use types in the loam Acrisol soil correlated with Bray-extractable soil P $(\rho=-0.74, P=$ $0.04, n=8$ ). Furthermore, annual soil $\mathrm{CH}_{4}$ fluxes from both reference land-use types across landscapes were correlated with net $\mathrm{N}$ mineralization rates $(\rho=-0.75, P<0.01, n=$ 16) and, for each landscape separately, with exchangeable Al $(\rho=0.74, P=0.04, n=8$ in the clay Acrisol soil, and $\rho=0.69, P=0.06, n=8$ in the loam Acrisol soil).

Second, analyzing across four land-use types within each landscape, annual soil $\mathrm{CO}_{2}$ fluxes correlated only with soil ${ }^{15} \mathrm{~N}$ natural abundance signatures in the clay Acrisol soil ( $\rho=-0.49, P=0.05, n=16)$. In the loam Acrisol soil, annual soil $\mathrm{CO}_{2}$ fluxes correlated with soil organic $\mathrm{C}(\rho=0.49$, $P=0.06, n=16)$, base saturation $(\rho=-0.53, P=0.04$, $n=16)$, Bray-extractable P $(\rho=-0.71, P<0.01, n=16)$ 

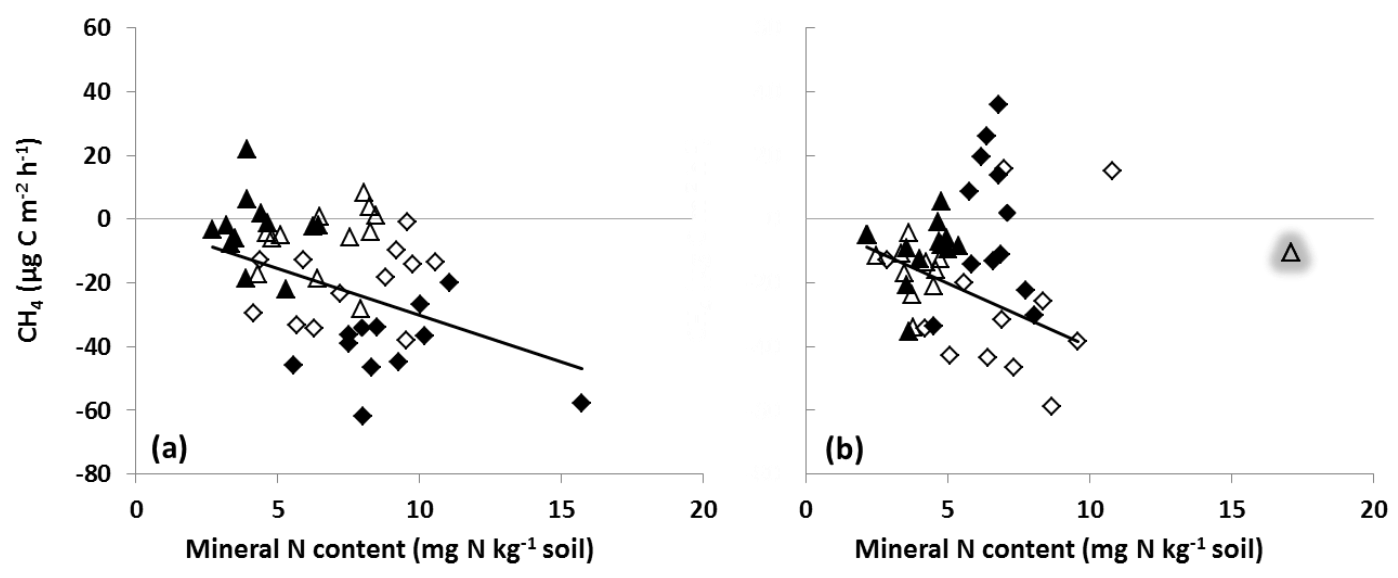

Figure 3. Relationship between soil $\mathrm{CH}_{4}$ uptake and soil mineral $\mathrm{N}$ content, using the monthly-measurement means of four replicate plots per land-use type between December 2012 and December 2013: forest $(\diamond)$, jungle rubber $(\diamond)$, rubber $(\Delta)$ and oil palm $(\triangle)$ on the clay Acrisol soil (Pearson correlation: $R=-0.47, P=0.01, n=41$ ) (a) and the loam Acrisol soil (Pearson correlation: $R=-0.52, P<0.01, n=38$ ) (b). Correlations exclude net $\mathrm{CH}_{4}$ emissions (fluxes above 0) in both landscapes and an outlier plot of oil palm on the loam Acrisol soil (shaded grey).

and soil ${ }^{15} \mathrm{~N}$ natural abundance signatures $(\rho=-0.60$, $P=0.02, n=16)$. Annual soil $\mathrm{CH}_{4}$ fluxes across all landuse types in the clay Acrisol soil correlated with net $\mathrm{N}$ mineralization rates $(\rho=-0.52, P=0.04, n=16)$, whereas in the loam Acrisol soil this correlation only showed up after the exclusion of one plot in rubber that had an unusually high net $\mathrm{N}$ mineralization $(\rho=-0.51, P=0.07, n=15)$. Net $\mathrm{N}$ mineralization significantly decreased in rubber that had no fertilization and was intermediate in oil palm that had fertilization, particularly in the clay Acrisol soil (Table A1).

\section{Discussion}

\section{1 $\mathrm{CO}_{2}$ and $\mathrm{CH}_{4}$ fluxes from the reference land-use types}

Mean soil $\mathrm{CO}_{2}$ fluxes from our forest sites (Table 2) were within the range of reported fluxes $\left(123-228 \mathrm{mg} \mathrm{C} \mathrm{m}^{-2} \mathrm{~h}^{-1}\right)$ from tropical rainforests in Asia (Adachi et al., 2005; Ohashi et al., 2008) and Latin America (Davidson et al., 2000; Schwendenmann et al., 2003; Keller et al., 2005; Sotta et al., 2006; Koehler et al., 2009). Compared to measurements conducted in Indonesia, our lowland forests had higher soil $\mathrm{CO}_{2}$ fluxes than a montane forest in Sulawesi at $1000 \mathrm{~m}$ elevation with similar spatially replicated and temporally intensive measurements $\left(127 \mathrm{mg} \mathrm{C} \mathrm{m}^{-2} \mathrm{~h}^{-1}\right.$; van Straaten et al., 2011); fluxes were also higher than in the seven partially logged forest sites in Jambi, where measurements were only made once (162 $\mathrm{m} \mathrm{C} \mathrm{m}^{-2} \mathrm{~h}^{-1}$; Ishizuka et al., 2005). While the difference with this last study may be caused by their one-off sampling, the only other study that measured $\mathrm{CO}_{2}$ fluxes from the same region (which conducted nine measurements spread over 1 year at three plots) reported values that were as low as 33 to $50 \%$ of our measured soil $\mathrm{CO}_{2}$ fluxes (63-94 $\mathrm{mg} \mathrm{C} \mathrm{m}^{-2} \mathrm{~h}^{-1}$; Ishizuka et al., 2002). Such values are hard to reconcile with our measurements and those of others in tropical lowland forests, including the measurements by Ishizuka et al. (2005).

Seasonal variation in soil $\mathrm{CO}_{2}$ fluxes from the reference land-use types was driven by changes in soil water content, as suggested by the positive correlation with WFPS in jungle rubber on the loam Acrisol soil (Table 3). Other studies conducted in tropical rainforests have shown that seasonal changes in soil $\mathrm{CO}_{2}$ fluxes are often caused by changes in soil water content (e.g., Sotta et al., 2007; Koehler et al., 2009; van Straaten et al., 2011), sometimes in combination with a reduction in solar irradiation caused by clouds during the wet season (Schwendenmann et al., 2003). In tropical forest soils, the relationship of soil $\mathrm{CO}_{2}$ flux with soil water content is curvilinear, with the highest fluxes typically at field capacity ( $p F \sim 2$ or WFPS between 50 and $55 \%$; Sotta et al., 2007; Koehler et al., 2009; van Straaten et al., 2011), which explains why WFPS did not show correlation in forests in both landscapes where WFPS (mostly $\geq 60-80 \%$; Fig. 1a, b) fluctuated at the top curve of this curvilinear relationship.

In contrast to our first hypothesis, soil texture was not the proximal factor controlling annual soil $\mathrm{CO}_{2}$ fluxes, but instead sand content indirectly affected soil fertility (e.g., Brayextractable $\mathrm{P}$ ), which, in turn, influenced soil $\mathrm{CO}_{2}$ fluxes. In the reference land-use types, the negative correlation of annual soil $\mathrm{CO}_{2}$ fluxes with the sand contents contrasted with results in the Amazon Basin where sandy Ferralsol soil had higher soil $\mathrm{CO}_{2}$ fluxes than the clay Ferralsol soil (Sotta et al., 2006). In the study by Sotta et al. (2006), annual $\mathrm{CO}_{2}$ emissions were negatively correlated with total soil $\mathrm{P}$ content. In our loam Acrisol soil, which had lower soil fertility (i.e., lower Bray-extractable P and base saturation and 
Table 3. Pearson correlation coefficients $(n=12)$ between soil $\mathrm{CO}_{2}$ flux $\left(\mathrm{mg} \mathrm{C} \mathrm{m}^{-2} \mathrm{~h}^{-1}\right)$, soil $\mathrm{CH}_{4}$ flux $\left(\mu g \mathrm{Cm}^{-2} \mathrm{~h}^{-1}\right)$, soil temperature $\left({ }^{\circ} \mathrm{C}\right.$, top $0.05 \mathrm{~m}$ depth), water-filled pore space (WFPS) $\left(\%\right.$, top $0.05 \mathrm{~m}$ depth) and extractable mineral nitrogen $\left(\mathrm{mg} \mathrm{N} \mathrm{kg}^{-1}\right.$, top $0.05 \mathrm{~m}$ depth), using the monthly-measurement means of the four replicate plots per land-use type between December 2012 and December 2013.

\begin{tabular}{|c|c|c|c|c|c|c|c|}
\hline Land use & Variable & Soil $\mathrm{CH}_{4}$ flux & Soil temp. & WFPS & $\mathrm{NH}_{4}^{+}$ & $\mathrm{NO}_{3}^{-}$ & Min. N \\
\hline \multicolumn{8}{|c|}{ Clay Acrisol soil } \\
\hline Forest & $\begin{array}{l}\text { Soil } \mathrm{CO}_{2} \text { flux } \\
\text { Soil } \mathrm{CH}_{4} \text { flux } \\
\text { Soil temperature } \\
\text { WFPS }\end{array}$ & 0.19 & $\begin{array}{l}0.42 \\
0.25\end{array}$ & $\begin{array}{l}0.49 \\
0.68^{\mathrm{b}} \\
0.34\end{array}$ & $\begin{array}{l}-0.17 \\
0.18 \\
0.63^{b} \\
0.25\end{array}$ & $\begin{array}{l}0.37 \\
-0.59^{b} \\
-0.32 \\
-0.18\end{array}$ & $\begin{array}{l}-0.01 \\
-0.09 \\
0.54^{\mathrm{a}} \\
0.18\end{array}$ \\
\hline Jungle rubber & $\begin{array}{l}\text { Soil } \mathrm{CO}_{2} \text { flux } \\
\text { Soil } \mathrm{CH}_{4} \text { flux } \\
\text { Soil temperature } \\
\text { WFPS }\end{array}$ & -0.03 & $\begin{array}{l}0.38 \\
0.49\end{array}$ & $\begin{array}{l}0.21 \\
0.74^{\mathrm{c}} \\
0.78^{\mathrm{c}}\end{array}$ & $\begin{array}{l}-0.39 \\
0.33 \\
0.34 \\
0.25\end{array}$ & $\begin{array}{l}0.61^{\mathrm{b}} \\
-0.19 \\
0.19 \\
0.07\end{array}$ & $\begin{array}{l}0.27 \\
0.34 \\
0.39 \\
0.28\end{array}$ \\
\hline Rubber & $\begin{array}{l}\text { Soil } \mathrm{CO}_{2} \text { flux } \\
\text { Soil } \mathrm{CH}_{4} \text { flux } \\
\text { Soil temperature } \\
\text { WFPS }\end{array}$ & $-0.51^{\mathrm{a}}$ & $\begin{array}{l}0.49 \\
-0.14\end{array}$ & $\begin{array}{l}-0.39 \\
0.84^{\mathrm{c}} \\
-0.24\end{array}$ & $\begin{array}{l}0.05 \\
-0.06 \\
0.3 \\
-0.06\end{array}$ & $\begin{array}{l}0.14 \\
-0.52^{\mathrm{a}} \\
0.16 \\
-0.53^{\mathrm{a}}\end{array}$ & $\begin{array}{l}0.06 \\
-0.1 \\
0.31 \\
-0.1\end{array}$ \\
\hline Oil palm & $\begin{array}{l}\text { Soil } \mathrm{CO}_{2} \text { flux } \\
\text { Soil } \mathrm{CH}_{4} \text { flux } \\
\text { Soil temperature } \\
\text { WFPS }\end{array}$ & -0.29 & $\begin{array}{l}0.82^{\mathrm{c}} \\
-0.09\end{array}$ & $\begin{array}{l}-0.37 \\
0.69^{c} \\
-0.19\end{array}$ & $\begin{array}{l}0.31 \\
0.19 \\
0.32 \\
0.16\end{array}$ & $\begin{array}{l}0.24 \\
0.13 \\
0.32 \\
0.08\end{array}$ & $\begin{array}{l}0.41 \\
0.25 \\
0.52^{\mathrm{a}} \\
0.16\end{array}$ \\
\hline \multicolumn{8}{|c|}{ Loam Acrisol soil } \\
\hline Forest & $\begin{array}{l}\text { Soil } \mathrm{CO}_{2} \text { flux } \\
\text { Soil } \mathrm{CH}_{4} \text { flux } \\
\text { Soil temperature } \\
\text { WFPS }\end{array}$ & 0.12 & $\begin{array}{l}0.58^{b} \\
0.19\end{array}$ & $\begin{array}{l}0.05 \\
0.32 \\
0.42\end{array}$ & $\begin{array}{l}-0.12 \\
0.09 \\
0.41 \\
0.4\end{array}$ & $\begin{array}{l}0.23 \\
-0.24 \\
-0.03 \\
-0.33\end{array}$ & $\begin{array}{l}-0.01 \\
-0.24 \\
0.37 \\
0.23\end{array}$ \\
\hline Jungle rubber & $\begin{array}{l}\text { Soil } \mathrm{CO}_{2} \text { flux } \\
\text { Soil } \mathrm{CH}_{4} \text { flux } \\
\text { Soil temperature } \\
\text { WFPS }\end{array}$ & $0.74^{\mathrm{c}}$ & $\begin{array}{l}0.21 \\
0.35\end{array}$ & $\begin{array}{l}0.59^{\mathrm{b}} \\
0.74^{\mathrm{c}} \\
0.42\end{array}$ & $\begin{array}{l}-0.05 \\
0.35 \\
0.47 \\
0.32\end{array}$ & $\begin{array}{l}-0.60^{b} \\
-0.58^{b} \\
-0.22 \\
-0.67^{b}\end{array}$ & $\begin{array}{l}-0.41 \\
0.11 \\
0.38 \\
0.05\end{array}$ \\
\hline Rubber & $\begin{array}{l}\text { Soil } \mathrm{CO}_{2} \text { flux } \\
\text { Soil } \mathrm{CH}_{4} \text { flux } \\
\text { Soil temperature } \\
\text { WFPS }\end{array}$ & $-0.74^{\mathrm{c}}$ & $\begin{array}{l}0.16 \\
-0.07\end{array}$ & $\begin{array}{l}-0.54^{\mathrm{a}} \\
0.84^{\mathrm{c}} \\
0.07\end{array}$ & $\begin{array}{l}0.06 \\
0.33 \\
0.57^{\mathrm{b}} \\
0.23\end{array}$ & $\begin{array}{l}-0.07 \\
-0.11 \\
-0.42 \\
-0.24\end{array}$ & $\begin{array}{l}0.05 \\
0.32 \\
0.54^{\mathrm{a}} \\
0.2\end{array}$ \\
\hline Oil palm & $\begin{array}{l}\text { Soil } \mathrm{CO}_{2} \text { flux } \\
\text { Soil } \mathrm{CH}_{4} \text { flux } \\
\text { Soil temperature } \\
\text { WFPS }\end{array}$ & -0.05 & $\begin{array}{l}0.57^{\mathrm{a}} \\
0.16\end{array}$ & $\begin{array}{l}-0.29 \\
0.86^{\mathrm{c}} \\
0.08\end{array}$ & $\begin{array}{l}0.25 \\
0.06 \\
0.13 \\
-0.08\end{array}$ & $\begin{array}{l}0.36 \\
0.17 \\
-0.19 \\
-0.05\end{array}$ & $\begin{array}{l}-0.05 \\
0.1 \\
0.16 \\
-0.07\end{array}$ \\
\hline
\end{tabular}

${ }^{\mathrm{a}} P \leq 0.09,{ }^{\mathrm{b}} P \leq 0.05,{ }^{\mathrm{c}} P \leq 0.01$.

higher Al saturation) than the clay Acrisol soil (Table A1; Allen et al., 2015), there may be strong competition for $\mathrm{P}$ such that trees have to allocate more $\mathrm{C}$ to their root or rootmycorrhizal system to obtain this nutrient. At the same study sites, reference land-use types on loam Acrisol soil showed a lower $\mathrm{P}$ concentration in the fine roots in the top $0.2 \mathrm{~m}$ of soil than reference land-use types on clay Acrisol soil (Sah- ner et al., 2015). This strategy of high belowground $\mathrm{C}$ investment was reflected in the negative correlation of annual soil $\mathrm{CO}_{2}$ fluxes from the reference land-use types with Brayextractable P contents in the loam Acrisol soil.

Mean soil $\mathrm{CH}_{4}$ fluxes from our forest sites (Table 2) fall within the range for tropical lowland forests reported by other studies $\left(-6.3\right.$ to $-55.9 \mu \mathrm{g} \mathrm{CH}_{4}-\mathrm{C} \mathrm{m}^{-2} \mathrm{~h}^{-1}$; summarized by 
Veldkamp et al., 2013); however, our measured $\mathrm{CH}_{4}$ uptake rates were at the upper end (towards more negative values) of these reported rates and were also higher than the $\mathrm{CH}_{4}$ uptake rates reported for old-growth forests in Jambi, Indonesia ( -21.3 to $+4.2 \mu \mathrm{g} \mathrm{CH}_{4}-\mathrm{C} \mathrm{m}^{-2} \mathrm{~h}^{-1}$; Ishizuka et al., 2002).

Seasonal variation in soil $\mathrm{CH}_{4}$ fluxes was strongly controlled by soil water content with higher uptake in the dry season (Fig. 1a, b), as shown by the strong positive correlations with WFPS in all land-use types in both landscapes (Table 3). Such seasonal changes reflect diffusional limitation on the supply of $\mathrm{CH}_{4}$ to methanotrophs at high WFPS (Keller and Reiners, 1994) and the possible occurrence of anaerobic decomposition, producing $\mathrm{CH}_{4}$, which may partially offset $\mathrm{CH}_{4}$ consumption (Keller and Reiners, 1994; Verchot et al., 2000). Since we measured occasional net $\mathrm{CH}_{4}$ emissions from some reference land-use types (Fig. 2d), we cannot exclude this anaerobic $\mathrm{CH}_{4}$ production. High microbial and root activity consume oxygen in the soil, which may contribute to the creation of anaerobic microsites where $\mathrm{CH}_{4}$ can be produced. This may have occurred in the jungle rubber on the loam Acrisol soil, where we detected a positive correlation of soil $\mathrm{CO}_{2}$ fluxes with soil $\mathrm{CH}_{4}$ fluxes (Table 3). Positive correlations of soil $\mathrm{CO}_{2}$ fluxes and $\mathrm{CH}_{4}$ fluxes have been reported also for tropical forests (Verchot et al., 2000). In addition to WFPS, soil mineral $\mathrm{N}$ dynamics also influenced the seasonal variation in soil $\mathrm{CH}_{4}$ fluxes. The negative correlations of soil $\mathrm{CH}_{4}$ fluxes with soil $\mathrm{NO}_{3}^{-}$contents in the forest on the clay Acrisol soil and in the jungle rubber on the loam Acrisol soil (Table 3) imply that some of the observed seasonal variability may have been caused by temporal N limitation of $\mathrm{CH}_{4}$ oxidation (Bodelier and Laanbroek, 2004; Veldkamp et al. 2013).

We found strong indications that $\mathrm{CH}_{4}$ uptake in this converted tropical lowland was both $\mathrm{N}$-limited and affected by high, potentially toxic, exchangeable $\mathrm{Al}$ concentrations in the soil. We interpreted negative correlations of annual soil $\mathrm{CH}_{4}$ fluxes from the reference land-use types with net $\mathrm{N}$ mineralization rates (see Sect. 3.4) across landscapes as evidence for $\mathrm{N}$-limited $\mathrm{CH}_{4}$ uptake. Indications of $\mathrm{N}$-limited $\mathrm{CH}_{4}$ uptake have been reported for tropical forests in Panama (Veldkamp et al., 2013) and Ecuador (Wolf et al., 2012), but this is the first time that it was observed on a landscape scale in the tropics. Furthermore, the positive correlations of annual soil $\mathrm{CH}_{4}$ fluxes from the reference land-use types with exchangeable $\mathrm{Al}$ within each landscape reflected the lower $\mathrm{CH}_{4}$ uptake measured at sites with more exchangeable $\mathrm{Al}$ in the soil. Soil Al saturation in our reference land-use types was high (mean values ranged from 61 to $80 \%$; Appendix Table A1). High $\mathrm{Al}^{3+}$ concentrations in the soil solution and higher exchangeable $\mathrm{Al}$ in the soil are known to be toxic for plants, the root growth of which may be inhibited (Ma et al., 2001). Dissolved $\mathrm{Al}^{3+}$ can also be toxic for soil microorganisms, and it has been shown that high dissolved $\mathrm{Al}$ concentrations in the soil inhibited $\mathrm{CH}_{4}$ uptake in a temperate forest soil in Japan (Tamai et al., 2003). We are not aware of any study reporting such a relationship for tropical ecosystems, which is not surprising since in most trace gas studies exchangeable $\mathrm{Al}$ in the soil is either not measured or does not reach such high levels as at our sites.

In summary, seasonal variation in soil $\mathrm{CO}_{2}$ fluxes from the reference land-use types were related to soil water content (i.e., jungle rubber in loam Acrisol soil), while the spatial control of annual soil $\mathrm{CO}_{2}$ fluxes across landscapes was related to soil fertility: low Bray-extractable $\mathrm{P}$ concentrations coincided with high annual soil $\mathrm{CO}_{2}$ fluxes from the loam Acrisol soil, which had lower soil fertility than the clay Acrisol soil. Seasonal variation in $\mathrm{CH}_{4}$ fluxes from the reference land-use types were mainly explained by soil water content, although we found indications that temporal $\mathrm{N}$ limitation may also have played a role. Spatial controls of annual soil $\mathrm{CH}_{4}$ fluxes across landscapes were also related to soil fertility, as shown by their negative correlation with soil $\mathrm{N}$ availability, suggesting $\mathrm{N}$ limitation on $\mathrm{CH}_{4}$ uptake, and their positive correlation with exchangeable $\mathrm{Al}$, suggesting $\mathrm{Al}$ toxicity towards methanotrophs, which has not yet been reported for tropical ecosystems. These results are in contrast to our first hypothesis - soil texture was not the proximal factor controlling soil $\mathrm{CO}_{2}$ and $\mathrm{CH}_{4}$ fluxes but only did so indirectly through its influence on soil fertility, which, in turn, controlled the spatial variations in these trace gases across our studied landscapes.

\subsection{Effects of land-use change on $\mathrm{CO}_{2}$ and $\mathrm{CH}_{4}$ fluxes}

Mean soil $\mathrm{CO}_{2}$ fluxes from our rubber plantations (Table 2) were on the same order of magnitude as those reported for seven rubber plantations in Jambi (Indonesia) where fluxes were measured once $\left(171 \mathrm{mg} \mathrm{C} \mathrm{m}^{-2} \mathrm{~h}^{-1}\right.$; Ishizuka et al., 2005), while soil $\mathrm{CO}_{2}$ fluxes from a rubber plantation in a sandy clay loam Nitisol soil in Malaysia with one measurement were lower $\left(123 \mathrm{mg} \mathrm{C} \mathrm{m}^{-2} \mathrm{~h}^{-1}\right.$; Adachi et al., 2005). Some other studies reported soil $\mathrm{CO}_{2}$ fluxes that are much lower than our measured fluxes: at a rubber plantation on a heavily weathered silty clay soil in China (35 $\mathrm{mg} \mathrm{C} \mathrm{m}^{-2} \mathrm{~h}^{-1}$; Werner et al., 2006) and a rubber plantation in Jambi (Indonesia) with nine measurements $(75 \mathrm{mg}$ $\mathrm{C} \mathrm{m}^{-2} \mathrm{~h}^{-1}$; Ishizuka et al., 2002). Since this last study also reported $33-50 \%$ lower soil $\mathrm{CO}_{2}$ fluxes from forests (see Sect. 4.1) as well as $50 \%$ lower soil $\mathrm{CO}_{2}$ fluxes from oil palm (51 $\mathrm{mg} \mathrm{C} \mathrm{m}^{-2} \mathrm{~h}^{-1}$; Ishizuka et al., 2002) than our measured fluxes from the same region (Table 2), we suspect some methodological issues in this study. Mean soil $\mathrm{CO}_{2}$ fluxes from our oil palm sites were comparable with other reported fluxes from five oil palm plantations in Jambi (Indonesia) where fluxes were measured once $\left(98 \mathrm{mg} \mathrm{Cm}^{-2} \mathrm{~h}^{-1}\right.$; Ishizuka et al., 2005). Lastly, soil $\mathrm{CO}_{2}$ fluxes from an oil palm plantation that were more than double our measured fluxes were reported from a one-time measurement in a sandy clay loam Nitisol soil in Malaysia $\left(222 \mathrm{mg} \mathrm{C} \mathrm{m}^{-2} \mathrm{~h}^{-1}\right.$; Adachi et al., 2005). 
Seasonal variation in soil $\mathrm{CO}_{2}$ fluxes from oil palm was not as pronounced as that in fluxes from rubber (Fig. 2a, b). In rubber plantations in loam Acrisol soil, where WFPS were all above $55 \%$ (Fig. 1b), the seasonal variation in soil $\mathrm{CO}_{2}$ fluxes reflected the curvilinear relationship of soil $\mathrm{CO}_{2}$ fluxes with WFPS, whereby soil $\mathrm{CO}_{2}$ fluxes typically decline at WFPS larger than about $55 \%$ (e.g., Sotta et al., 2007; Koehler et al., 2009), hence the negative correlation with WFPS (Table 3).

The spatial variation in annual soil $\mathrm{CO}_{2}$ fluxes across landuse types reflected the changes in soil organic-matter quality and quantity with changes in land use, as indicated by the negative correlations with soil ${ }^{15} \mathrm{~N}$ natural abundance signatures (see Sect. 3.4) and the positive correlation with soil organic $\mathrm{C}$ content. Soil ${ }^{15} \mathrm{~N}$ signatures in our studied oil palm plantations were significantly higher than in the reference land-use types (i.e., loam Acrisol soil; Table A1; Allen et al., 2015), which we interpreted as an indication of the degree of decomposition of soil organic matter. The more decomposed the soil organic matter, the higher the soil ${ }^{15} \mathrm{~N}$ signature, as illustrated by increasing soil ${ }^{15} \mathrm{~N}$ signatures with increasing depth of tropical forest soils (Sotta et al., 2008; Baldos et al., 2015). The more decomposed soil organic matter in the oil palm plantations was probably caused by reduced litter input and lower fine- and coarse-root production compared to the forests (measured at the same sites by Kotowska et al., 2015). The low litter input and root production influenced not only the degree of decomposition of the soil organic matter but also led to strong reductions in soil organic $\mathrm{C}$ stocks of oil palm and rubber plantations (measured in the same study region by van Straaten et al., 2015). This may have contributed to the low $\mathrm{CO}_{2}$ emissions, since we also detected a positive correlation of soil $\mathrm{CO}_{2}$ emissions with soil organic $\mathrm{C}$ content. Similar findings were reported from the conversion of forest to tree plantations on Acrisol soil in subtropical southern China, where decreases in soil $\mathrm{CO}_{2}$ fluxes were also explained by decreases in annual litterfall and root biomass (Sheng et al., 2010). In addition to changes in soil organic-matter quality, spatial variation in annual soil $\mathrm{CO}_{2}$ fluxes across land-use types in the loam Acrisol soil was also controlled by changes in soil fertility with land-use change, as shown by the fluxes' negative correlations with base saturation and Bray-extractable $\mathrm{P}$ (see Sect. 3.4). Conversion of forest or jungle rubber to rubber and oil palm plantations was accompanied by the burning of slashed vegetation, whereby considerable amounts of bases and $\mathrm{P}$ could be released from the plant biomass to ashes (Klinge et al., 2004). Input of these nutrients to the soil from the ashes, combined with $\mathrm{P}$ fertilization and liming (particularly in the oil palm plantations), significantly increased soil $\mathrm{pH}$ in both rubber and oil palm as well as base saturation and Bray-extractable $\mathrm{P}$ in oil palm (Table A1; Allen et al., 2015). The negative correlations of annual soil $\mathrm{CO}_{2}$ fluxes with base saturation and Bray-extractable $\mathrm{P}$ across land-use types suggest that $\mathrm{C}$ allocation to its root-mycorrhizal system may have decreased with increased base cations and $\mathrm{P}$ availability, contributing to the observed decrease in soil $\mathrm{CO}_{2}$ fluxes from oil palm compared to the other land-use types (Table 2). In contrast, we could not support the speculation by Ishizuka et al. (2005) that low soil $\mathrm{CO}_{2}$ fluxes from oil palm plantations could be explained by higher soil bulk densities related to intensive management practices since soil bulk densities in these converted land-use types were comparable to the reference landuse types (Table A1; Allen et al., 2015).

Mean soil $\mathrm{CH}_{4}$ fluxes from rubber plantations (Table 2) were comparable with those reported for a rubber plantation in southwest China $\left(-5.7 \mu \mathrm{g} \mathrm{CH}_{4}-\mathrm{C} \mathrm{m}^{-2} \mathrm{~h}^{-1}\right.$; Werner et al., 2006) and for seven rubber plantations in Jambi (Indonesia) measured only once $\left(-5.8 \mu \mathrm{g} \mathrm{CH}_{4}-\mathrm{C} \mathrm{m}^{-2} \mathrm{~h}^{-1}\right.$; Ishizuka et al., 2005). From the oil palm plantations, mean soil $\mathrm{CH}_{4}$ fluxes (Table 2) were comparable with those reported for five oil palm plantations in Jambi (Indonesia), where fluxes were measured only once $\left(-20.1 \mu \mathrm{g} \mathrm{CH}_{4}-\mathrm{C} \mathrm{m}^{-2} \mathrm{~h}^{-1}\right.$; Ishizuka et al., 2005), but larger (or higher $\mathrm{CH}_{4}$ uptake rate) than the values reported for an oil palm plantation in Jambi with one measurement (-4.2 $\mu \mathrm{g} \mathrm{CH}_{4}-\mathrm{C} \mathrm{m}^{-2} \mathrm{~h}^{-1}$; Ishizuka et al., 2002).

As was the case for the reference land-use types, seasonal variation in soil $\mathrm{CH}_{4}$ fluxes from the converted landuse types was also controlled by WFPS (Table 3), and the possible mechanisms were the same (see Sect. 4.1). Moreover, strong negative correlations of soil $\mathrm{CH}_{4}$ uptake with total mineral $\mathrm{N}$ (Fig. 3) and $\mathrm{NO}_{3}^{-}$contents across all landuse types (see Sect. 3.3), with total mineral $\mathrm{N}$ being lowest in the converted land-use types (Table 1), also suggest temporal $\mathrm{N}$ limitation on methanotrophic activity (Veldkamp et al., 2013) that may have contributed to the decrease in $\mathrm{CH}_{4}$ uptake in the converted land-use types (Fig. 2c, d; Table 2).

The negative correlations of annual soil $\mathrm{CH}_{4}$ fluxes with net $\mathrm{N}$ mineralization rates across land-use types further suggest $\mathrm{N}$ limitation on $\mathrm{CH}_{4}$ uptake, as indicated by the lowest $\mathrm{CH}_{4}$ uptake in the converted land-use types (Table 2) that had the lowest (i.e., rubber with no $\mathrm{N}$ fertilization) to intermediate (i.e., oil palm with $\mathrm{N}$ fertilization) net $\mathrm{N}$ mineralization rates (see Sect. 3.4). The results from the fertilization experiment in the oil palm sites that showed inhibition of $\mathrm{CH}_{4}$ uptake in the fertilized spot (chamber location b; Table A3) within 6 weeks following fertilizer application (Fig. B1) were probably caused by salt effect, as has been observed in a fertilization experiment in tropical pastures (Veldkamp et al., 2001). However, this $\mathrm{CH}_{4}$ inhibition following fertilizer application did not influence our annual flux estimates because of the negligible area coverage of the fertilized spots $(\sim 1.3 \%$ of 1 ha) and its short-term effect $(12 \%$ of 1 year).

In summary, soil $\mathrm{CO}_{2}$ fluxes decreased only in oil palm and not in rubber, which partly supports our second hypothesis. These converted land-use types showed a decrease in soil $\mathrm{CH}_{4}$ uptake, which supports our second hypothesis. Seasonality of soil $\mathrm{CO}_{2}$ and $\mathrm{CH}_{4}$ fluxes in the converted land-use 
types appeared to be controlled by the same factors as in the reference land-use types. The strong decrease in soil $\mathrm{CO}_{2}$ fluxes from the oil palm was probably caused by a combination of strongly decomposed soil organic matter and low soil carbon stocks (caused by the low input of litterfall and low fine-root production) and possibly by low $\mathrm{C}$ allocation to the root or the root-mycorrhizal system (due to the improved base cations and $\mathrm{P}$ availability from liming and $\mathrm{P}$ fertilization). Reduction in annual $\mathrm{CH}_{4}$ uptake in the converted land-use types was primarily caused by the decrease in soil $\mathrm{N}$ availability in these converted land-use types.

\section{Consequences of land-use change for soil trace gas fluxes}

Our study shows that land-use change had a profound effect on the soil-atmosphere fluxes of the trace gases $\mathrm{CO}_{2}$ and $\mathrm{CH}_{4}$, with reduced soil $\mathrm{CO}_{2}$ fluxes from oil palm plantations and reduced soil $\mathrm{CH}_{4}$ uptake in both rubber and oil palm plantations. The reduced soil $\mathrm{CO}_{2}$ fluxes in the oil palm should not be interpreted as reduced net ecosystem emissions because we did not measure the net $\mathrm{CO}_{2}$ uptake by the vegetation and the changes in soil and vegetation carbon stocks. Rather the strong decrease in soil $\mathrm{CO}_{2}$ fluxes from oil palm is a reflection of the present belowground carbon dynamics in this land-use type. Due to decreases in litterfall and fineroot production (Kotowska et al., 2015) as well as frond management practice (stacking fronds in interrows) that reduced fresh litter input in the whole area, soil organic C stocks in these oil palm plantations decreased over time (van Straaten et al., 2015), reflecting the reductions in soil $\mathrm{CO}_{2}$ emissions.
Our estimate of the decrease in $\mathrm{CH}_{4}$ uptake resulting from conversion of forest or jungle rubber to rubber and oil palm in these landscapes was about $2 \mathrm{~kg} \mathrm{CH}_{4}-\mathrm{Cha}^{-1} \mathrm{yr}^{-1}$ (based on the average of the values in Table 2 ). If we multiply this with $0.52 \mathrm{Mha}$, the increase in areal coverage of oil palm and rubber plantations in Jambi from 1996 to 2011 (BPS, 2012), this suggests that the capacity of the province of Jambi to remove this potent greenhouse gas from the atmosphere has decreased by about $1040 \mathrm{Mg} \mathrm{CH}_{4}-\mathrm{C} \mathrm{yr}^{-1}$ as a result of this land-use conversion. This calculation does not take into account land-use changes that occurred in the peatlands. Finally, we detected important soil fertility controls on trace gas exchange in this converted tropical landscape on highly weathered Acrisol soils, including the controls of base cation and $\mathrm{P}$ availability on annual soil $\mathrm{CO}_{2}$ fluxes and $\mathrm{N}$ availability and $\mathrm{Al}$ toxicity on annual soil $\mathrm{CH}_{4}$ fluxes. Such controls on the landscape scale have not yet been reported, and thus we stress the importance of conducting landscape-scale studies as field studies on a few small plots or laboratory-based studies may not be able to detect such important controls. 


\section{Appendix A: Soil sampling and analysis}

Soil samples were taken from 10 subplots per plot that were randomly selected and at least $5 \mathrm{~m}$ distance from the plot's border. Soil characteristics for each replicate plot were the average of the 10 subplots. Soil sampling was conducted between June 2013 and December 2013. Soil samples were taken at various depth intervals down to $2 \mathrm{~m}$, and we report here the values from the top depth interval $(0-0.1 \mathrm{~m})$, except for soil texture, which we report for the entire $2 \mathrm{~m}$. Soil texture was analyzed using the wet sieving and pipette methods. Soil bulk density was measured using the core method. Soil $\mathrm{pH}\left(\mathrm{H}_{2} \mathrm{O}\right)$ was analyzed in a $1: 4$ soil-to-water ratio. Soil organic $\mathrm{C}$ and total $\mathrm{N}$ concentrations were analyzed from airdried, sieved $(2 \mathrm{~mm})$ and ground samples using a $\mathrm{CN}$ analyzer (Vario EL Cube, Elementar Analysis Systems GmbH, Hanau, Germany). Air-dried and sieved soils were used to determine effective cation exchange capacity (ECEC) by percolating with unbuffered $1 \mathrm{~mol} \mathrm{~L}^{-1} \mathrm{NH}_{4} \mathrm{Cl}$, and cations $(\mathrm{Ca}$, $\mathrm{Mg}, \mathrm{K}, \mathrm{Na}, \mathrm{Al}, \mathrm{Fe}$, and $\mathrm{Mn}$ ) were measured in percolate using an inductively coupled plasma-atomic emission spectrometer (iCAP 6300 Duo VIEW ICP Spectrometer, Thermo Fischer Scientific GmbH, Dreieich, Germany). Base and aluminum saturation were calculated as the percentage of exchangeable base cations and aluminum of the ECEC. Extractable P was determined using the Bray 2 method, which is typically used for acidic tropical soils. For soil ${ }^{15} \mathrm{~N}$ natural abundance signatures, ground soil samples were analyzed using isotope ratio mass spectrometry (IRMS; Delta Plus, Finnigan MAT, Bremen, Germany). The net $\mathrm{N}$ mineralization rate was measured in two subplots per plot that were at least $10 \mathrm{~m}$ from the plot's border, using the buried-bag method on intact soil cores incubated in situ for 7 days. This was conducted between January 2013 and May 2013 during the rainy season. The field extraction of the soil with $0.5 \mathrm{M} \mathrm{K}_{2} \mathrm{SO}_{4}$, analysis of $\mathrm{NH}_{4}^{+}$and $\mathrm{NO}_{3}^{-}$concentrations, and calculation of rate are used are the same as described in our earlier work (Arnold et al., 2008). The net $\mathrm{N}$ mineralization rate for each plot was the average of two subplots. 
Table A1. Mean $( \pm \mathrm{SE}, n=4)$ soil physical and biochemical characteristics in the top $0.10 \mathrm{~m}$ depth (except for the clay content, $0-2 \mathrm{~m}$ depth with $n=3$ ) for different land-use types within each soil landscape in Jambi, Sumatra, Indonesia. Means followed by different lowercase letters indicate significant differences among land-use types within each soil landscape and different capital letters indicate significant differences between soil landscapes within a land-use type (linear mixed-effect models with Fisher's LSD test at $P \leq 0.05$ and marginally significant at ${ }^{*} P \leq 0.09$ ). Soil characteristics were measured by Allen et al. (unpublished data). Soil sampling and analysis are described in Appendix A.

\begin{tabular}{|c|c|c|c|c|}
\hline \multirow[t]{2}{*}{ Soil characteristics } & \multicolumn{4}{|c|}{ Land use } \\
\hline & Forest & Jungle rubber & Rubber & Oil palm \\
\hline \multicolumn{5}{|l|}{ Clay Acrisol soil } \\
\hline Clay $(0-0.5 \mathrm{~m})(\%)$ & $31.4 \pm 5.4^{\mathrm{a}}$ & $47.2 \pm 12.40^{\mathrm{a}}$ & $42.4 \pm 3.1^{\mathrm{a}}$ & $59.7 \pm 5.2^{\mathrm{a}, \mathrm{A}}$ \\
\hline Clay $(0.5-1.0 \mathrm{~m})(\%)$ & $34.9 \pm 9.0^{\mathrm{b} *}$ & $51.4 \pm 12.6^{\mathrm{ab} *}$ & $36.8 \pm 8.00^{\mathrm{b} *}$ & $69.7 \pm 4.8^{\mathrm{a} * \mathrm{~A}}$ \\
\hline Clay $(1.0-1.5 \mathrm{~m})(\%)$ & $39.0 \pm 13.0^{\mathrm{a}}$ & $62.8 \pm 12.6^{\mathrm{a}}$ & $40.8 \pm 10.3^{\mathrm{a}}$ & $62.8 \pm 3.6^{\mathrm{a}, \mathrm{A}}$ \\
\hline Clay $(1.5-2.0 \mathrm{~m})(\%)$ & $41.3 \pm 11.2^{\mathrm{a}}$ & $46.6 \pm 16.2^{\mathrm{a}}$ & $36.5 \pm 10.8^{\mathrm{a}}$ & $63.3 \pm 6.1^{\mathrm{a}, \mathrm{A}}$ \\
\hline Sand $(0-0.10 \mathrm{~m})(\%)$ & $36 \pm 11^{\mathrm{a}}$ & $27 \pm 20^{\mathrm{a}}$ & $35 \pm 7^{\mathrm{a}}$ & $11 \pm 2^{\mathrm{a}, \mathrm{B} *}$ \\
\hline Bulk density $\left(\mathrm{g} \mathrm{cm}^{-3}\right)$ & $1.0 \pm 0.1^{\mathrm{a}}$ & $0.8 \pm 0.1^{\mathrm{a}}$ & $0.9 \pm 0.1^{\mathrm{a}}$ & $0.9 \pm 0.1^{\mathrm{a}, \mathrm{B}}$ \\
\hline $\mathrm{pH}\left(1: 4 \mathrm{H}_{2} \mathrm{O}\right)$ & $4.2 \pm 0.4^{\mathrm{b}}$ & $4.5 \pm 0.0^{\mathrm{a}, \mathrm{A}}$ & $4.5 \pm 0.1^{\mathrm{a}}$ & $4.4 \pm 0.1^{\mathrm{a}}$ \\
\hline Soil organic $\mathrm{C}\left(\mathrm{kgCm}^{-2}\right)$ & $3.3 \pm 0.5^{\mathrm{a}}$ & $4.3 \pm 0.4^{\mathrm{a}, \mathrm{A}}$ & $2.8 \pm 0.4^{\mathrm{a}}$ & $3.5 \pm 0.2^{\mathrm{a}, \mathrm{A}}$ \\
\hline Total $\mathrm{N}\left(\mathrm{g} \mathrm{N} \mathrm{m}^{-2}\right)$ & $263.4 \pm 67.1^{\mathrm{a}}$ & $331.4 \pm 34.1^{\mathrm{a}, \mathrm{A}}$ & $198.4 \pm 32.5^{\mathrm{a}}$ & $260.2 \pm 22.6^{\mathrm{a}, \mathrm{A}}$ \\
\hline $\mathrm{C}: \mathrm{N}$ ratio & $13.1 \pm 1.3^{\mathrm{a}}$ & $13.0 \pm 0.3^{\mathrm{a}}$ & $14.3 \pm 0.6^{\mathrm{a}, \mathrm{A}}$ & $13.5 \pm 0.2^{\mathrm{a}}$ \\
\hline Effective cation exchange capacity $\left(\mathrm{cmol}_{3} \mathrm{~kg}^{-1}\right)$ & $9.4 \pm 4.1^{\mathrm{a}}$ & $12.4 \pm 2.6^{\mathrm{a}, \mathrm{A}}$ & $7.1 \pm 2.2^{\mathrm{a}}$ & $7.8 \pm 0.8^{\mathrm{a}, \mathrm{A}}$ \\
\hline Base saturation $(\%)$ & $23 \pm 6^{\mathrm{a}, \mathrm{A}}$ & $23 \pm 6^{\mathrm{a}}$ & $20 \pm 3^{\mathrm{a}}$ & $38 \pm 7^{\mathrm{a}}$ \\
\hline Aluminum saturation $(\%)$ & $61 \pm 3^{\mathrm{ab}, \mathrm{B}}$ & $71 \pm 6^{\mathrm{a}}$ & $73 \pm 4^{\mathrm{a}}$ & $53 \pm 7^{\mathrm{b}}$ \\
\hline Bray-extractable phosphorus $\left(\mathrm{gPm}^{-2}\right)$ & $1.4 \pm 0.1^{\mathrm{a}, \mathrm{b}, \mathrm{A}}$ & $0.8 \pm 0.1^{\mathrm{bc}}$ & $0.4 \pm 0.0^{\mathrm{c}}$ & $4.7 \pm 1.5^{\mathrm{a}, \mathrm{A} *}$ \\
\hline${ }^{15} \mathrm{~N}$ natural abundance $(\% o)$ & $4.5 \pm 0.0^{\mathrm{a}}$ & $4.0 \pm 0.3^{\mathrm{a}}$ & $4.6 \pm 0.4^{\mathrm{a}}$ & $5.2 \pm 0.4^{\mathrm{a}}$ \\
\hline Net $\mathrm{N}$ mineralization $\left(\mathrm{mg} \mathrm{Nkg}^{-1} \mathrm{~d}^{-1}\right)$ & $1.2 \pm 0.3^{\mathrm{a}}$ & $0.5 \pm 0.0^{\mathrm{b}}$ & $0.5 \pm 0.2^{b}$ & $0.9 \pm 0.2^{\mathrm{ab}}$ \\
\hline \multicolumn{5}{|l|}{ Loam Acrisol soil } \\
\hline Clay $(0-0.5 \mathrm{~m})(\%)$ & $26.0 \pm 2.6^{\mathrm{a}}$ & $30.6 \pm 4.6^{\mathrm{a}}$ & $37.3 \pm 10.3^{\mathrm{a}}$ & $33.4 \pm 2.2^{\mathrm{a}, \mathrm{B}}$ \\
\hline Clay $(0.5-1.0 \mathrm{~m})(\%)$ & $28.7 \pm 4.8^{\mathrm{a}}$ & $38.8 \pm 9.0^{\mathrm{a}}$ & $45.1 \pm 11.3^{\mathrm{a}}$ & $41.0 \pm 3.1^{\mathrm{a}, \mathrm{B}}$ \\
\hline Clay $(1.0-1.5 \mathrm{~m})(\%)$ & $33.3 \pm 7.56^{\mathrm{a}}$ & $42.4 \pm 9.9^{\mathrm{a}}$ & $46.1 \pm 9.9^{\mathrm{a}}$ & $43.3 \pm 2.8^{\mathrm{a}, \mathrm{B}}$ \\
\hline Clay $(1.5-2.0 \mathrm{~m})(\%)$ & $37.3 \pm 8.7^{\mathrm{a}}$ & $44.5 \pm 10.0^{\mathrm{a}}$ & $43.4 \pm 6.5^{\mathrm{a}}$ & $47.6 \pm 4.5^{\mathrm{a}, \mathrm{B}}$ \\
\hline Sand $(0-0.10 \mathrm{~m})(\%)$ & $39 \pm 8^{\mathrm{a}}$ & $42 \pm 19^{\mathrm{a}}$ & $26 \pm 13^{\mathrm{a}}$ & $43 \pm 14^{1, \mathrm{~A} *}$ \\
\hline Bulk density $\left(\mathrm{g} \mathrm{cm}^{-3}\right)$ & $1.0 \pm 0.0^{\mathrm{ab}}$ & $0.9 \pm 0.0^{\mathrm{b}}$ & $1.1 \pm 0.1^{\mathrm{a}}$ & $1.1 \pm 0.1^{\mathrm{a}, \mathrm{A}}$ \\
\hline $\mathrm{pH}\left(1: 4 \mathrm{H}_{2} \mathrm{O}\right)$ & $4.3 \pm 0.0^{\mathrm{b} *}$ & $4.3 \pm 0.0^{\mathrm{b} *, \mathrm{~B}}$ & $4.5 \pm 0.1^{\mathrm{ab} *}$ & $4.5 \pm 0.1^{\mathrm{a} *}$ \\
\hline Soil organic $\mathrm{C}\left(\mathrm{kgCm}^{-2}\right)$ & $2.6 \pm 0.2^{\mathrm{a}}$ & $2.7 \pm 0.3^{\mathrm{a}, \mathrm{B}}$ & $2.0 \pm 0.3^{\mathrm{a}}$ & $1.8 \pm 0.2^{\mathrm{a}, \mathrm{B}}$ \\
\hline Total $\mathrm{N}\left(\mathrm{g} \mathrm{m}^{-2}\right)$ & $182.9 \pm 10.8^{\mathrm{a}}$ & $186.19 \pm 11.0^{\mathrm{a}, \mathrm{B}}$ & $172.6 \pm 23.8^{\mathrm{a}}$ & $145.0 \pm 13.5^{\mathrm{a}, \mathrm{B}}$ \\
\hline $\mathrm{C}: \mathrm{N}$ ratio & $14.3 \pm 0.2^{\mathrm{a}}$ & $13.7 \pm 0.8^{\mathrm{a}}$ & $11.7 \pm 0.7^{\mathrm{b}, \mathrm{B}}$ & $12.5 \pm 0.5^{\mathrm{ab}}$ \\
\hline Effective cation exchange capacity $\left(\mathrm{mmol}_{3} \mathrm{~kg}^{-1}\right)$ & $4.5 \pm 0.5^{\mathrm{a}}$ & $4.1 \pm 0.8^{\mathrm{a}, \mathrm{B}}$ & $4.6 \pm 0.5^{\mathrm{a}}$ & $4.0 \pm 0.8^{\mathrm{a}, \mathrm{B}}$ \\
\hline Base saturation $(\%)$ & $11 \pm 1^{\mathrm{b} * \mathrm{~B}}$ & $16 \pm 2^{\mathrm{ab} *}$ & $21 \pm 8^{\mathrm{ab} *}$ & $28 \pm 5^{\mathrm{a} *}$ \\
\hline Aluminum saturation $(\%)$ & $80 \pm 1^{\mathrm{a}, \mathrm{A}}$ & $78 \pm 2^{\mathrm{a}}$ & $73 \pm 8^{\mathrm{a}}$ & $67 \pm 5^{\mathrm{a}}$ \\
\hline Bray-extractable phosphorus $\left(\mathrm{gPm}^{-2}\right)$ & $0.5 \pm 0.1^{\mathrm{aB}}$ & $0.7 \pm 0.1^{\mathrm{a}}$ & $0.5 \pm 0.1^{\mathrm{a}}$ & $0.8 \pm 0.1^{\mathrm{aB} *}$ \\
\hline${ }^{15} \mathrm{~N}$ natural abundance $(\% o)$ & $4.3 \pm 0.2^{b}$ & $4.5 \pm 0.1^{\mathrm{b}}$ & $5.0 \pm 0.4^{\mathrm{ab}}$ & $5.4 \pm 0.3^{\mathrm{a}}$ \\
\hline Net $\mathrm{N}$ mineralization $\left(\mathrm{mg} \mathrm{N} \mathrm{kg}^{-1} \mathrm{~d}^{-1}\right)$ & $0.8 \pm 0.2^{\mathrm{a}}$ & $0.7 \pm 0.1^{\mathrm{a}}$ & $0.7 \pm 0.3^{\mathrm{a}}$ & $0.5 \pm 0.2^{\mathrm{a}}$ \\
\hline
\end{tabular}


Table A2. Plantation age and mean $( \pm \mathrm{SE}, n=4)$ tree density, tree height, basal area, diameter at breast height $(\mathrm{DBH})$ of trees with $\geq 0.10 \mathrm{~m}$ $\mathrm{DBH}$ and the most common tree species for different land-use types within each soil landscape in Jambi, Sumatra, Indonesia.

\begin{tabular}{|c|c|c|c|c|c|c|}
\hline Land-use type & $\begin{array}{l}\text { Age range } \\
\text { (years) }\end{array}$ & $\begin{array}{l}\text { Tree density } \\
\left(\mathrm{nha}^{-1}\right)^{\mathrm{a}}\end{array}$ & $\begin{array}{l}\text { Tree height } \\
(\mathrm{m})^{\mathrm{a}}\end{array}$ & $\begin{array}{l}\text { Basal area } \\
\left(\mathrm{m}^{2} \mathrm{ha}^{-1}\right)^{\mathrm{a}}\end{array}$ & $\begin{array}{l}\mathrm{DBH} \\
(\mathrm{cm})^{\mathrm{a}}\end{array}$ & $\begin{array}{l}\text { Most common tree } \\
\text { species }^{b}\end{array}$ \\
\hline \multicolumn{7}{|c|}{ Clay Acrisol soil } \\
\hline Forest & not determined (ND) & $471 \pm 31$ & $17.0 \pm 0.5$ & $29.4 \pm 1.7$ & $23.0 \pm 0.4$ & $\begin{array}{l}\text { Archidendron sp., } \\
\text { Baccaurea spp., } \\
\text { Ochanostachys sp. }\end{array}$ \\
\hline Jungle rubber & ND & $685 \pm 72$ & $15.2 \pm 0.3$ & $21.1 \pm 1.4$ & $17.3 \pm 0.6$ & $\begin{array}{l}\text { Artocarpus spp., Endospermum sp., } \\
\text { Hevea sp., Macaranga spp. }\end{array}$ \\
\hline Rubber & $7-16$ & $497 \pm 15$ & $13.4 \pm 0.1$ & $10.0 \pm 1.4$ & $15.2 \pm 0.7$ & Hevea brasiliensis \\
\hline Oil palm & $9-13$ & $134 \pm 6$ & $4.0 \pm 0.3$ & $\mathrm{n} / \mathrm{a}$ & $\mathrm{n} / \mathrm{a}$ & Elaeis guineensis \\
\hline \multicolumn{7}{|c|}{ Loam Acrisol soil } \\
\hline Forest & ND & $658 \pm 26$ & $20.0 \pm 0.6$ & $30.7 \pm 1.0$ & $21.0 \pm 0.5$ & $\begin{array}{l}\text { Aporosa spp., Burseraceae spp., } \\
\text { Dipterocarpaceae spp., Fabaceae spp., } \\
\text { Gironniera spp., Myrtaceae spp., } \\
\text { Plaquium spp., Porterandia sp., Shorea spp. }\end{array}$ \\
\hline Jungle rubber & ND & $525 \pm 60$ & $14.0 \pm 0.2$ & $16.6 \pm 0.4$ & $16.8 \pm 0.5$ & $\begin{array}{l}\text { Alstonia spp., Artocarpus spp., Fabaceae sp., } \\
\text { Hevea sp., Macaranga } \text { spp., Porterandia sp., } \\
\text { Sloetia sp. }\end{array}$ \\
\hline Rubber & $14-17$ & $440 \pm 81$ & $13.4 \pm 0.5$ & $12.2 \pm 1.6$ & $17.8 \pm 1.2$ & Hevea brasiliensis \\
\hline Oil palm & $12-16$ & $140 \pm 4$ & $4.9 \pm 0.6$ & $\mathrm{n} / \mathrm{a}$ & $\mathrm{n} / \mathrm{a}$ & Elaeis guineensis \\
\hline
\end{tabular}

${ }^{\text {a }}$ Kotowska et al. (2015). ${ }^{\mathrm{b}}$ Rembold et al. (unpublished data), based on trees found in five subplots $(5 \mathrm{~m} \times 5 \mathrm{~m})$ of each replicate plot $(50 \mathrm{~m} \times 50 \mathrm{~m})$ which had $\geq 20$ individuals, except in the case of Fabaceae spp. which had $\leq 20$ individuals. 
Table A3. Mean ( \pm SE, $n=3$ oil palm trees) soil $\mathrm{CO}_{2}$ and $\mathrm{CH}_{4}$ fluxes from three different chamber locations during a fertilization in three oil palm plantations within each soil landscape, measured 6 to 11 times during 3-8.5 weeks following fertilization. Means followed by different letters indicate significant differences among chamber locations within each oil palm plantation site (linear mixed-effect models with Fisher's LSD test at $P \leq 0.05$ ). Chamber locations a, $\mathrm{b}$ and $\mathrm{c}$ were placed at $0.3,0.8$, and $4-4.5 \mathrm{~m}$, respectively, from each of the three trees at each oil palm plantation site. Smallholders fertilized the area around the base of each tree about $0.8-1 \mathrm{~m}$ from the tree base, and thus chamber location $\mathrm{b}$ was on this fertilized area and chamber location $\mathrm{c}$ serves as the reference chamber not receiving any fertilizer. The same fertilization rate and form as applied by the smallholders were used in these studied oil palm plantations, described in $\mathrm{Sect}^{2} 2.2$ " $\mathrm{CO}_{2}$ and $\mathrm{CH}_{4}$ flux measurement".

\begin{tabular}{|c|c|c|c|}
\hline $\begin{array}{l}\text { Oil palm } \\
\text { plantation site }\end{array}$ & $\begin{array}{l}\text { Chamber } \\
\text { location }\end{array}$ & $\begin{array}{l}\mathrm{CO}_{2} \text { fluxes } \\
\left(\mathrm{mgCm}^{-2} \mathrm{~h}^{-1}\right)\end{array}$ & $\begin{array}{l}\mathrm{CH}_{4} \text { fluxes } \\
\left(\mu \mathrm{g} \mathrm{Cm}{ }^{-2} \mathrm{~h}^{-1}\right)\end{array}$ \\
\hline \multicolumn{4}{|c|}{ Clay Acrisol soil } \\
\hline \multirow[t]{3}{*}{1} & $\mathrm{a}$ & $272.83 \pm 36.68^{\mathrm{a}}$ & $-23.66 \pm 2.56^{\mathrm{b}}$ \\
\hline & $\mathrm{b}$ & $218.25 \pm 25.91^{b}$ & $-12.61 \pm 5.12^{\mathrm{a}}$ \\
\hline & $\mathrm{c}$ & $103.56 \pm 11.72^{\mathrm{c}}$ & $-16.66 \pm 8.68^{a b}$ \\
\hline \multirow[t]{3}{*}{2} & $\mathrm{a}$ & $226.16 \pm 38.17^{\mathrm{a}}$ & $-28.44 \pm 1.48^{\mathrm{b}}$ \\
\hline & $\mathrm{b}$ & $246.39 \pm 42.80^{\mathrm{a}}$ & $-6.64 \pm 2.07^{\mathrm{a}}$ \\
\hline & $\mathrm{c}$ & $86.04 \pm 7.83^{b}$ & $-10.60 \pm 5.29^{\mathrm{a}}$ \\
\hline \multirow[t]{3}{*}{3} & $\mathrm{a}$ & $222.56 \pm 72.49^{b}$ & $-8.13 \pm 4.77^{\mathrm{a}}$ \\
\hline & $\mathrm{b}$ & $311.63 \pm 89.87^{\mathrm{a}}$ & $-10.38 \pm 3.61^{\mathrm{a}}$ \\
\hline & $\mathrm{c}$ & $105.49 \pm 12.06^{\mathrm{c}}$ & $-14.49 \pm 2.03^{\mathrm{a}}$ \\
\hline \multicolumn{4}{|c|}{ Loam Acrisol soil } \\
\hline \multirow[t]{3}{*}{1} & $\mathrm{a}$ & $334.67 \pm 32.12^{\mathrm{a}}$ & $-14.00 \pm 3.31^{\mathrm{b}}$ \\
\hline & $\mathrm{b}$ & $378.47 \pm 50.97^{\mathrm{a}}$ & $-4.12 \pm 2.24^{\mathrm{a}}$ \\
\hline & c & $160.35 \pm 20.48^{b}$ & $-18.53 \pm 1.32^{b}$ \\
\hline \multirow[t]{3}{*}{2} & $\mathrm{a}$ & $271.35 \pm 17.31^{\mathrm{a}}$ & $-13.18 \pm 1.22^{\mathrm{a}}$ \\
\hline & $\mathrm{b}$ & $233.27 \pm 18.98^{b}$ & $-8.63 \pm 0.52^{\mathrm{a}}$ \\
\hline & $\mathrm{c}$ & $127.66 \pm 17.13^{\mathrm{c}}$ & $-19.47 \pm 5.08^{\mathrm{b}}$ \\
\hline \multirow[t]{3}{*}{3} & $\mathrm{a}$ & $240.81 \pm 23.12^{\mathrm{a}}$ & $-28.13 \pm 3.40^{\mathrm{b}}$ \\
\hline & $\mathrm{b}$ & $243.92 \pm 24.23^{\mathrm{a}}$ & $-10.34 \pm 2.70^{\mathrm{a}}$ \\
\hline & $\mathrm{c}$ & $136.55 \pm 19.08^{b}$ & $-29.41 \pm 2.39^{b}$ \\
\hline
\end{tabular}




\section{Appendix B}

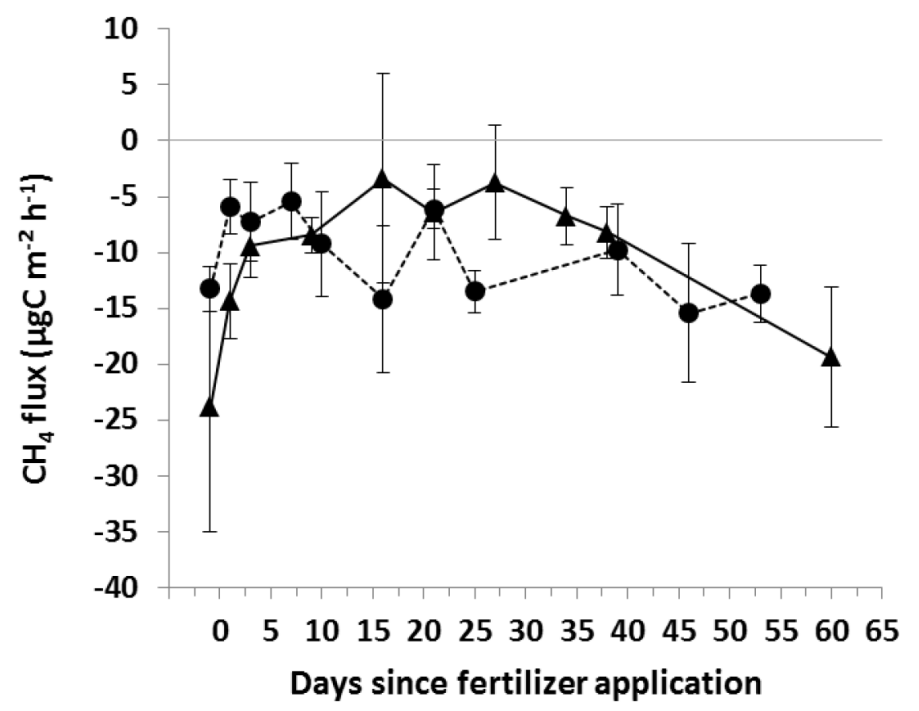

Figure B1. Mean ( $\pm \mathrm{SE}, n=3$ oil palm trees) soil $\mathrm{CH}_{4}$ fluxes during a fertilization at one oil palm plantation site in the clay Acrisol

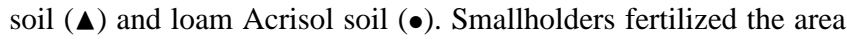
around the base of each tree at about $0.8-1 \mathrm{~m}$ from the tree base, and fluxes were measured on this fertilized location (chamber location b) at the same rate and form that smallholders applied in these oil palm plantations (described in Sect. 2.2 " $\mathrm{CO}_{2}$ and $\mathrm{CH}_{4}$ flux measurement"). 
Acknowledgements. We thank the village leaders, local plot owners, PT REKI, PT Perkebunan Nusantara VI, and Bukit Duabelas National Park for granting us access to and use of their properties. This study was financed by the Deutsche Forschungsgemeinschaft (DFG) as part of the project A05 in the framework of the German-Indonesian Collaborative Research Center 990: Ecological and Socioeconomic Function of Tropical Lowland Rainforest Transformation Systems. We are especially grateful to our Indonesian assistants, Edward Januarlin Siahaan, Nelson Apriadi Silalahi, Ardi, Fahrurrozy and Edi, as well as all the rangers of the protected forest areas. We also acknowledge the other members of project A05 (Allen et al., 2015; Kurniawan et al., unpublished data) for the soil physical and biochemical data (Table A1); projects B04 (Kotowska et al., 2015), B06 (Rembold et al., unpublished data) and B07 (Sahner et al., 2015) for the litterfall and root production, root nutrient concentrations and vegetation characteristics (Table A2); and project C07 (Euler et al., unpublished data) for information on land-use history. We also thank Norman Loftfield, Oliver van Straaten, Andrea Bauer, Kerstin Langs and Martina Knaust (Georg August University Göttingen, Germany) for their assistance with laboratory analyses. This study was conducted using the research permits (210/SIP/FRP/SM/VI/2012 and 45/EXT/SIP/FRP/SM/V/2013) issued by the Ministry of Research and Technology of Indonesia (RISTEK) and the collection permits (2703/IPH.1/KS.02/XI/2012 and S.13/KKH-2/2013) recommended by the Indonesian Institute of Sciences (LIPI) and issued by the Ministry of Forestry of Indonesia (PHKA).

This open-access publication was funded by the University of Göttingen.

Edited by: M. Williams

\section{References}

Adachi, M., Bekku, Y. S., Konuma, A., Kadir, W. R., Okuda, T., and Koizumi, H.: Required sample size for estimating soil respiration rates in large areas of two tropical forests and of two types of plantation in Malaysia, Forest Ecol. Manag., 210, 455-459, 2005.

Allen, K., Corre, M. D., Tjoa, A., and Veldkamp, E.: Soil nitrogencycling responses to conversion of lowland forests to oil palm and rubber plantations in Sumatra, Indonesia, PLoS ONE, 10, e0133325. doi:10.1371/journal.pone.0133325, 2015.

Arnold, J., Corre, M. D., and Veldkamp, E.: Cold storage and laboratory incubation of intact soil cores do not reflect in-situ nitrogen cycling rates of tropical forest soils, Soil Biol. Biochem., 40, 2480-2483, 2008.

Baldos, A. P., Corre, M. D., and Veldkamp, E.: Response of N cycling to nutrient inputs in forest soils across a 1000-3000m elevation gradient in the Ecuadorian Andes, Ecology, 96, 749-761, 2015.

Bodelier, P. L. E. and Laanbroek, H. J.: Nitrogen as a regulatory factor of methane oxidation in soils and sediments, FEMS Microbiol. Ecol., 47, 265-277, 2004.
BPS (Badan Pusat Statistik): Statistical Oce of Jambi Province, available at: http://jambi.bps.go.id/index. php?option=com_content $\&$ view $=$ article \&id $=164$ :

jambi-dalamangka-2011\&catid=5:publikasi-buku\&Itemid=30 (last access: 8 January 2014), 2012.

Carlson, K. M., Curran, L. M., Asner, G. P., Pittman, A. M., Trigg, S. N., and Marion Adeney, J.: Carbon emissions from forest conversion by Kalimantan oil palm plantations, Nature Climate Change, 3, 283-287, 2013.

Clay, J.: World Agriculture and the Environment: a Commodity-ByCommodity Guide to Impacts and Practices, Island Press, Washington DC, USA, 2013.

Crawley, M. J.: The R Book, John Wiley \& Sons Ltd, Chichester, UK, 2009.

Danielsen, F., Beukema, H., Burgess, N. D., Parish, F., Bruehl, C. A., Donald, P. F., Murdiyarso, D., Phalan, B., Reijnders, L., and Struebig, M.: Biofuel plantations on forested lands: double jeopardy for biodiversity and climate, Conserv. Biol., 23, 348-358, 2009.

Davidson, E. A., Verchot, L. V., Cattanio, J. H., Ackerman, I. L., and Carvalho, J. E. M.: Effects of soil water content on soil respiration in forests and cattle pastures of eastern Amazonia, Biogeochemistry, 48, 53-69, 2000.

Dechert, G., Veldkamp, E., and Anas, I.: Is soil degradation unrelated to deforestation?, Examining soil parameters of land use systems in upland Central Sulawesi, Indonesia, Plant Soil, 265, 197-209, 2004.

FAO, IIASA, ISRIC, ISS-CAS, and JRC: Harmonized World Soil Database (version 1.1), FAO, Rome, Italy \& IIASA, Laxenburg, Austria, 2009.

Food and Agricultural Organization: FAOSTAT Database, available at: http://faostat.fao.org/site/339/default.aspx (last access: 5 November 2014), 2014.

Gouyon, A., de Foresta, H., and Levang, P.: Does "jungle rubber" deserve its name?, An analysis of rubber agroforestry systems in southeast Sumatra, Agroforest. Syst., 22, 181-206, 1993.

Hedin, L. O., Brookshire, E. N. J., Menge, D. N. L., and Barron, A. R.: The nitrogen paradox in tropical forest ecosystems, Annu. Rev. Ecol. Evol. S., 40, 613-635, 2009.

Indonesian Ministry of Agriculture: Statistical Yearbook of Crops for 2009-2013, Directorate General of Estate Crops, Jakarta, 2014.

IPCC: Climate Change 2007: The Physical Science Basis, Contribution of Working Group I to the Fourth Assessment Report of the Intergovernmental Panel on Climate Change, Cambridge University Press, Cambridge, UK, New York, USA, 2007.

Ishizuka, S., Tsuruta, H., and Murdiyarso, D.: An intensive field study on $\mathrm{CO}_{2}, \mathrm{CH}_{4}$, and $\mathrm{N}_{2} \mathrm{O}$ emissions from soils at four landuse types in Sumatra, Indonesia, Global Biogeochem. Cy., 16, 22-1-22-11 doi:10.1029/2001GB001614, 2002.

Ishizuka, S., Iswandi, A., Nakajima, Y., Yonemura, S., Sudo, S., Tsuruta, H., and Murdiyarso, D.: The variation of greenhouse gas emissions from soils of various land-use/cover types in Jambi province, Indonesia, Nutr. Cycl. Agroecosys., 71, 17-32, 2005.

Keller, M. and Reiners, W. A.: Soil-atmosphere exchange of nitrous oxide, nitric oxide and methane under secondary succession of pasture to forest in the Atlantic lowlands of Costa Rica, Global Biogeochem. Cy., 8, 399-409, 1994. 
Keller, M., Veldkamp, E., Weitz, A. M., and Reiners, W. A.: Effect of pasture age on soil trace gas emissions from a deforested area of Costa Rica, Nature, 365, 244-246, 1993.

Keller, M., Varner, R., Dias, J. D., Silva, H., Crill, P., and de Oliveira, R. C.: Soil-atmosphere exchange of nitrous oxide, nitric oxide, methane, and carbon dioxide in logged and undisturbed forest in the Tapajos National Forest, Brazil, Earth Interact., 9, 1-28, 2005.

Klinge, R., Martins, A. R. A., Mackensen, J., and Folster, H.: Element loss on rain forest conversion in East Amazonia: comparison of balances of stores and fluxes, Biogeochemistry, 69, 63-82, 2004.

Koehler, B., Corre, M. D., Veldkamp, E., and Sueta, J. P.: Chronic nitrogen addition causes a reduction in soil carbon dioxide efflux during the high stem-growth period in a tropical montane forest but no response from a tropical lowland forest on a decadal time scale, Biogeosciences, 6, 2973-2983, doi:10.5194/bg-6-29732009, 2009.

Koh, L. P. and Ghazoul, J.: Spatially explicit scenario analysis for reconciling agricultural expansion, forest protection, and carbon conservation in Indonesia, P. Natl. Acad. Sci. USA, 107, 1114011144, 2010.

Kotowska, M. M., Leuschner, C., Triadiati, T., Meriem, S., and Hertel, D.: Quantifying above and belowground biomass carbon loss with forest conversion in tropical lowlands of Sumatra (Indonesia), Glob. Change Biol., 21, 3620-3634, doi:10.1111/gcb.12979, 2015.

Laumonier, Y., Uryu, Y., Stüwe, M., Budiman, A., Setiabudi, B., and Hadian, O.: Eco-floristic sectors and deforestation threats in Sumatra: identifying new conservation area network priorities for ecosystem-based land use planning, Biodivers. Conserv., 19, 1153-1174, 2010.

Ma, J. F., Ryan, P. R., and Delhaize, E.: Aluminium tolerance in plants and the complexing role of organic acids, Trends Plant Sci., 6, 273-278, 2001.

Margono, B. A., Turubanova, S., Zhuravleva, I., Potapov, P., Tyukavina, A., Baccini, A., Goetz, S., and Hansen, M. C.: Mapping and monitoring deforestation and forest degradation in Sumatra (Indonesia) using Landsat time series data sets from 1990 to 2010, Environ. Res. Lett., 7, 034010, doi:10.1088/17489326/7/3/034010, 2012.

Melling, L., Hatano, R., and Goh, K. J.: Methane fluxes from three ecosystems in tropical peatland of Sarawak, Malaysia, Soil Biol. Biochem., 37, 1445-1453, 2005a.

Melling, L., Hatano, R., and Goh, K. J.: Soil $\mathrm{CO}_{2}$ flux from three ecosystems in tropical peatland of Sarawak, Malaysia, Tellus B, 57, 1-11, 2005b.

Ohashi, M., Kumagai, T. O., Kume, T., Gyokusen, K., Saitoh, T. M., and Suzuki, M.: Characteristics of soil $\mathrm{CO}_{2}$ efflux variability in an aseasonal tropical rainforest in Borneo Island, Biogeochemistry, 90, 275-289, 2008.

R Development Core Team: R: a Language and Environment For Statistical Computing, R Foundation for Statistical Computing, Vienna, Austria, 2013.

Raich, J. W. and Schlesinger, W. H.: The global carbon dioxide flux in soil respiration and its relationship to vegetation and climate, Tellus B, 44, 81-99, 1992.

Sahner, J., Budi, S. W., Barus, H., Edy, N., Meyer, M., Corre, M. D., and Polle, A.: Degradation of root community traits as in- dicator for transformation of tropical lowland rain forests into oil palm and rubber plantations, PLoS ONE, 10, e0138077, doi:10.1371/journal.pone.013807, 2015.

Salimon, C., Davidson, E., Victoria, R., and Melo, A.: $\mathrm{CO}_{2}$ flux from soil in pastures and forests in southwestern Amazonia, Glob. Change Biol., 10, 833-843, 2004.

Schwendenmann, L., Veldkamp, E., Brenes, T., O’Brien, J. J., and Mackensen, J.: Spatial and temporal variation in soil $\mathrm{CO}_{2}$ efflux in an old-growth neotropical rain forest, La Selva, Costa Rica, Biogeochemistry, 64, 111-128, 2003.

Seiler, W., Conrad, R., and Scharffe, D.: Field studies of methane emission from termite nests into the atmosphere and measurements of methane uptake by tropical soils, J. Atmos. Chem., 1, 171-186, 1984.

Sheng, H., Yang, Y., Yang, Z., Chen, G., Xie, J., Guo, J., and Zou, S.: The dynamic response of soil respiration to land-use changes in subtropical China, Glob. Change Biol., 16, 1107-1121, 2010.

Sotta, E. D., Veldkamp, E., Guimarães, B. R., Paixão, R. K., Ruivo, M. L. P., and Almeida, S. S.: Landscape and climatic controls on spatial and temporal variation in soil $\mathrm{CO}_{2}$ efflux in an Eastern Amazonian Rainforest, Caxiuanã, Brazil, Forest Ecol. Manag., 237, 57-64, 2006.

Sotta, E. D., Veldkamp, E., Schwendenmann, L., Guimarães, B. R., Paixão, R. K., Ruivo, M. D. L. P., Lola da Costa, A. C., and Meir, P.: Effects of an induced drought on soil carbon dioxide $\left(\mathrm{CO}_{2}\right)$ efflux and soil $\mathrm{CO}_{2}$ production in an Eastern Amazonian rainforest, Brazil, Glob. Change Biol., 13, 2218-2229, 2007.

Sotta, E. D., Corre, M. D., and Veldkamp, E.: Differing N status and $\mathrm{N}$ retention processes of soils under old-growth lowland forest in Eastern Amazonia, Caxiuanã, Brazil, Soil Biol. Biochem., 40, 740-750, 2008.

Tamai, N., Takenaka, C., Ishizuka, S., and Tezuka, T.: Methane flux and regulatory variables in soils of three equal-aged Japanese cypress (Chamaecyparis obtusa) forests in central Japan, Soil Biol. Biochem., 35, 633-641, 2003.

van Straaten, O., Veldkamp, E., and Corre, M. D.: Simulated drought reduces soil $\mathrm{CO}_{2}$ efflux and production in a tropical forest in Sulawesi, Indonesia, Ecosphere, 2, 119, doi:10.1890/ES1100079.1, 2011.

van Straaten, O., Corre, M. D., Wolf, K., Tchienkoua, M., Cuellar, E., Matthews, R. B., and Veldkamp, E.: Conversion of lowland tropical forests to tree cash crop plantations loses up to one-half of stored soil organic carbon, carbon. P. Natl. Acad. Sci. USA, 112, 9956-9960, 2015.

Veldkamp, E., Weitz, A. M., and Keller, M.: Management effects on methane fluxes in humid tropical pasture soils, Soil Biol. Biochem., 33, 1493-1499, 2001.

Veldkamp, E., Purbopuspito, J., Corre, M. D., Brumme, R., and Murdiyarso, D.: Land use change effects on trace gas fluxes in the forest margins of Central Sulawesi, Indonesia, J. Geophys. Res.-Biogeo., 113, G02003, doi:10.1029/2007JG000522, 2008.

Veldkamp, E., Koehler, B., and Corre, M. D.: Indications of nitrogen-limited methane uptake in tropical forest soils, Biogeosciences, 10, 5367-5379, doi:10.5194/bg-10-5367-2013, 2013.

Verchot, L. V., Davidson, E. A., Cattanio, J. H., and Ackerman, I. L.: Land-use change and biogeochemical controls of methane fluxes in soils of eastern Amazonia, Ecosystems, 3, 41-56, 2000.

Werner, C., Zheng, X., Tang, J., Xie, B., Liu, C., Kiese, R., and Butterbach-Bahl, K.: $\mathrm{N}_{2} \mathrm{O}, \mathrm{CH}_{4}$ and $\mathrm{CO}_{2}$ emissions from sea- 
sonal tropical rainforests and a rubber plantation in Southwest China, Plant Soil, 289, 335-353, 2006.
Wolf, K., Flessa, H., and Veldkamp, E.: Atmospheric methane uptake by tropical montane forest soils and the contribution of organic layers, Biogeochemistry, 111, 469-483, 2012. 